\title{
Design, Synthesis and Biological Evaluation of Bifunctional Inhibitors of Membrane Type 1 Matrix Metalloproteinase (MT1-MMP)
}

\section{Doretta Cuffaro, ${ }^{1}$ Elisa Nuti, ${ }^{1}$ Valentina Gifford, ${ }^{2}$ Noriko Ito, ${ }^{2}$ Caterina Camodeca, ${ }^{1}$ Tiziano}

Tuccinardi, ${ }^{1}$ Susanna Nencetti, ${ }^{1}$ Elisabetta Orlandini, ${ }^{3}$ Yoshifumi Itoh, ${ }^{2}$ and Armando Rossello ${ }^{1, *}$

${ }^{1}$ Department of Pharmacy, Università di Pisa, via Bonanno 6, 56126 Pisa, Italy.

${ }^{2}$ Kennedy Institute of Rheumatology, Nuffield Department of Orthopaedics, Rheumatology and Musculoskeletal Sciences, University of Oxford, Oxford OX3 7FY, United Kingdom

${ }^{3}$ Department of Earth Sciences, University of Pisa, Via Santa Maria 53, 56126 Pisa, Italy

\begin{abstract}
*Corresponding author: Armando Rossello, phone, +39 050 2219562, fax, +39 050 2219605, e-mail: armando.rossello@,farm.unipi.it
\end{abstract}

Keywords: MT1-MMP homodimerization, bifunctional inhibitors, arylsulfonamide hydroxamates, MMP inhibitors.

\begin{abstract}
Collagen degradation and proMMP-2 activation are major functions of MT1-MMP to promote cancer cell invasion. Since both processes require MT1-MMP homodimerization on the cell surface, herein we propose that the use of bifunctional inhibitors of this enzyme could represent an innovative approach to efficiently reduce tumor growth. A small series of symmetrical dimers derived from previously described monomeric arylsulfonamide hydroxamates was synthesized and tested in vitro on isolated MMPs. A nanomolar MT1-MMP inhibitor, compound 6, was identified and then submitted to cell-based assays on HT1080 fibrosarcoma cells. Dimer 6 reduced MT1-MMP-dependent proMMP-2 activation, collagen
\end{abstract}


degradation and collagen invasion in a dose-dependent manner with better results even compared to its monomeric analogue 4. This preliminary study suggests that dimeric MT1-MMP inhibitors might be further developed and exploited as an alternative tool to reduce cancer cell invasion.

\section{Introduction}

Matrix metalloproteinases (MMPs) are a family of zinc-dependent endopeptidases responsible for extracellular matrix (ECM) degradation and remodeling. In humans, there are $23 \mathrm{MMPs}$, classified into soluble and membrane-type MMPs (MT-MMPs). Soluble-types are secreted into the extracellular space and can diffuse into the ECM, while MT-MMPs are attached to the plasma membrane via a transmembrane (TM) domain (MT1-MMP, MT2-MMP, MT3-MMP, and MT5-MMP) or a glycosylphosphatidylinositol (GPI) anchor (MT4-MMP and MT6-MMP). ${ }^{1}$ MT1-MMP is one of the most studied enzymes in the MMP family. ${ }^{2}$ It is a proteolytic enzyme that has a broad substrate specificity, especially against ECM components: fibrillar collagens (type I, II, III), laminin-1 and -5, fibronectin, vitronectin, fibrin and aggrecan. ${ }^{3}$ MT1-MMP effectively promotes cell migration by degrading pericellular ECM at migration front of cell.

MT1-MMP can also degrade ECM components indirectly by activating proMMP- $2^{4}$ and proMMP- $13^{5}$. Active MMP-2 cleaves type IV collagen, one of the major components of the basement membrane, whose hydrolysis represents an important step for cancer invasion, growth and angiogenesis. ${ }^{6,7}$ MMP-2 activation process on the cell surface requires two MT1-MMP molecules forming a dimeric interaction through their hemopexin $(\mathrm{Hpx})^{8}$ and transmembrane (TM) domain. ${ }^{9}$ One of the dimer MT1-MMP is bound to its endogenous inhibitor, TIMP-2 (Tissue Inhibitor of Metalloproteinases), resulting in a trimeric complex. Once the trimolecular complex has been formed, exposed TIMP-2 C-terminal domain attracts proMMP-2 through binding its Hpx domain, and the other MT1-MMP that is not bound to TIMP2 can cleave the pro-domain of MMP-2, initiating activation. The disruption of the dimer formation effectively inhibits the MT1-MMP mediated proMMP-2 activation. ${ }^{8}$ Dimerization through its Hpx domain was also found to be crucial for MT1-MMP to degrade collagen on the cell surface. ${ }^{10}$

Given its involvement in cell migration, tumor growth and angiogenesis, many attempts have been made to develop selective inhibitors of MT1-MMP. Recent examples of inhibitors targeting the catalytic domain of MT1-MMPs are represented by a Val-PO - Leu phosphoroamidate scaffold developed by Mendes et $\mathrm{al}^{11}$ and by a cyclic peptide reported by Suojanen et $\mathrm{al}^{12}$. Accomplishing the required target specificity with small-molecule MMP-inhibitors (MMPIs) is exceedingly difficult, and so far, the success has been limited due to the high homology of the catalytic domain in the MMP family members. An 
alternative strategy to inhibit MT1-MMP could be targeting the hemopexin domain which is less conserved among MMPs than the catalytic site and was shown to be necessary for MT1-MMP dimerization. In this regards, Remacle et $\mathrm{al}^{13}$ in 2012 reported the first MT1-MMP hemopexin-targeting small molecule, NSC405020, able to inhibit in vivo the tumor growth of MCF7 cells in animal model of breast cancer. In the same years, other research groups identified anti-hemopexin domain inhibitors for MMP-9 able to reduce cell migration and tumor growth, ${ }^{14}$ thus validating this strategy. Our previous studies have shown that bifunctional ligands able to interact with the catalytic site of two MMP-9 monomers could be used to impair MMP-9 homodimerization by preventing the Hpx domains to approach each other. The best biological results were obtained with a dimeric dicarboxylate inhibitor (1, Figure 1), a nanomolar inhibitor of MMP-9, which was able to arrest cancer cell invasiveness in a human glioblastoma cell line. ${ }^{15}$ Moreover, we have already reported two potent MMP-2, MMP-9 and MT1MMP dimeric inhibitors 2 and 3 (Figure 1), endowed with an appreciably reduced cell toxicity with respect to their corresponding monomeric analogues. ${ }^{16}$
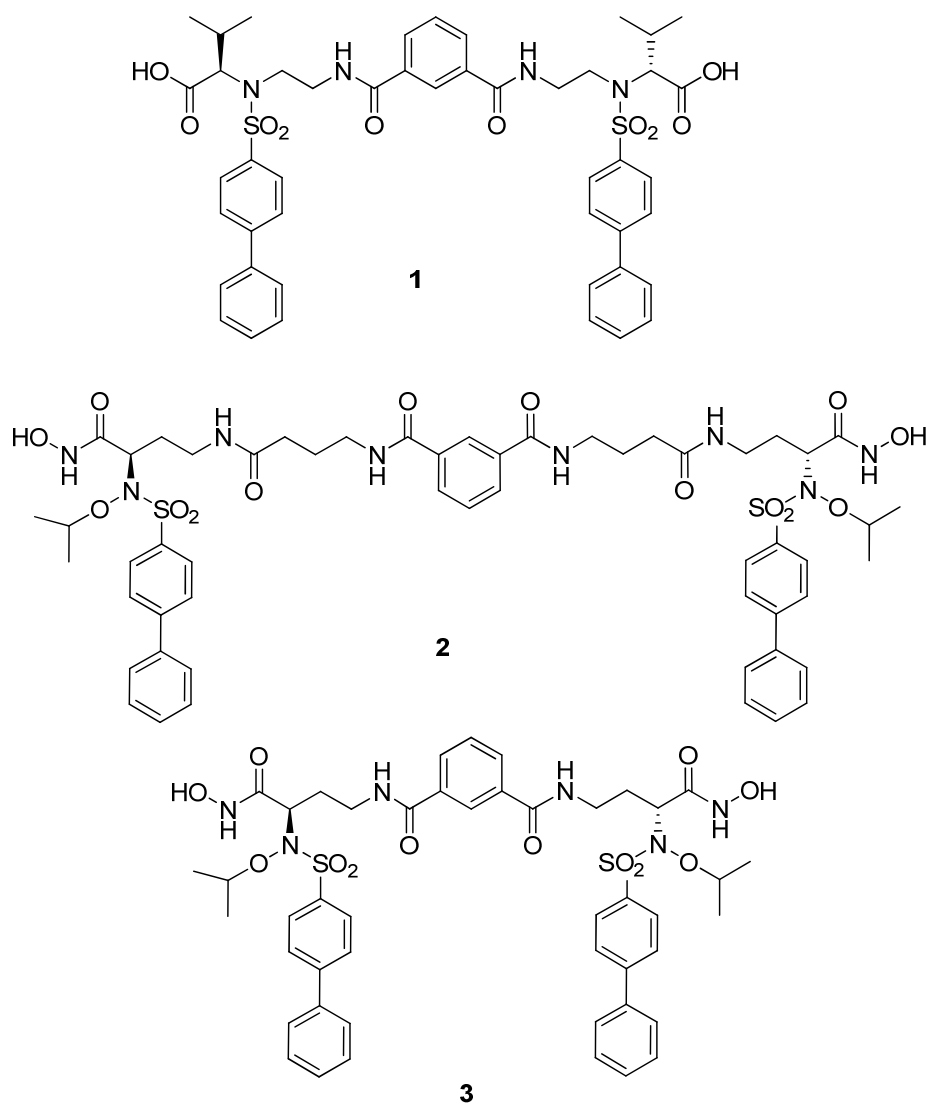

Figure 1. Structure of the previously reported dimeric MMP inhibitors 1, 2 and 3. 
Dimeric inhibitors have already been studied in several fields of medicinal chemistry, such as kinase inhibitors, HIV protease inhibitors, cholinesterase inhibitors and MMP inhibitors, with promising results. ${ }^{17,18}$

Based on these considerations, the aim of this work was to develop a new class of MT1-MMP bifunctional inhibitors able to potentially inhibit dimer MT1-MMP on tumor cell surface in efficient manner through the binding to the catalytic site of two MT1-MMP molecules. Looking into our in-house library of compounds, we chose two potent inhibitors of MT1-MMP, the $N$-isopropoxy-arylsulfonamide hydroxamate $4^{19}$ (Figure 2) and the arylsulfonamide $\mathbf{5}^{20}$ (Figure 3), as hit compounds to be modified. Both these derivatives had a nanomolar affinity for the target enzyme and $\mathbf{4}$ was able to potently arrest angiogenesis in vitro and also in vivo in the matrigel sponge assay in mice. X-ray crystallographic and docking studies performed on compound $\mathbf{4}$ have confirmed the importance of the phthalimidic group in $\mathrm{P} 1$ position to allow a good positioning of the molecule in the catalytic domain of MT1-MMP. ${ }^{19}$ On the basis of these findings, compounds $\mathbf{4}$ and $\mathbf{5}$ were taken as starting points to design new selective bifunctional inhibitors of MT1-MMP. We decided to synthesize and test compounds 6 and 7 (Figure 2) as dimeric derivatives of hydroxamate 4 . They maintained the phthalimidic group in P1 position and the p-methoxybiphenyl sulfonamido substituent in P1' necessary for a good fitting in the MT1-MMP catalytic domain. Moreover, they presented the dimerization in P2' position on the basis of the good results obtained with the bifunctional ligand of MMP-9, compound 1. In addition, we developed the bifunctional derivatives of 5, compounds 8 and 9 (Figure 3), dimerized in P1 position as reported for our previously published dimers 2 and 3. ${ }^{16}$ Dimers 6-9 were synthesized using both diethyleneisophthalamide (DEI) and $N$-N'-bis-(3-ethylencarbamoyl-propyl)-isophthalamide (BEPI) as linkers between the two chelating heads, in order to investigate the effect of dimers of different length on biological activity. 


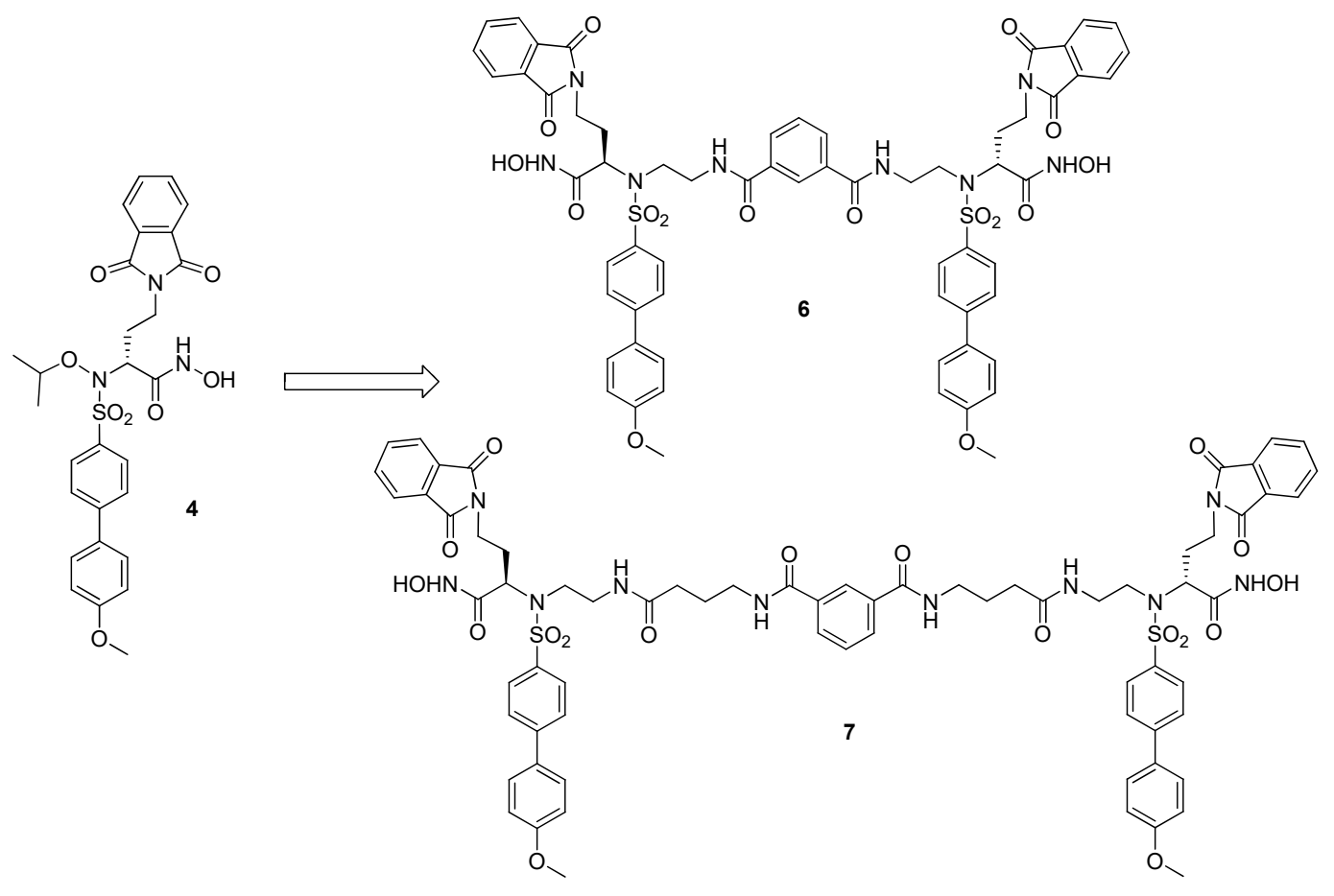

Figure 2. Structure of compound 4 and its dimeric derivatives 6 and 7.

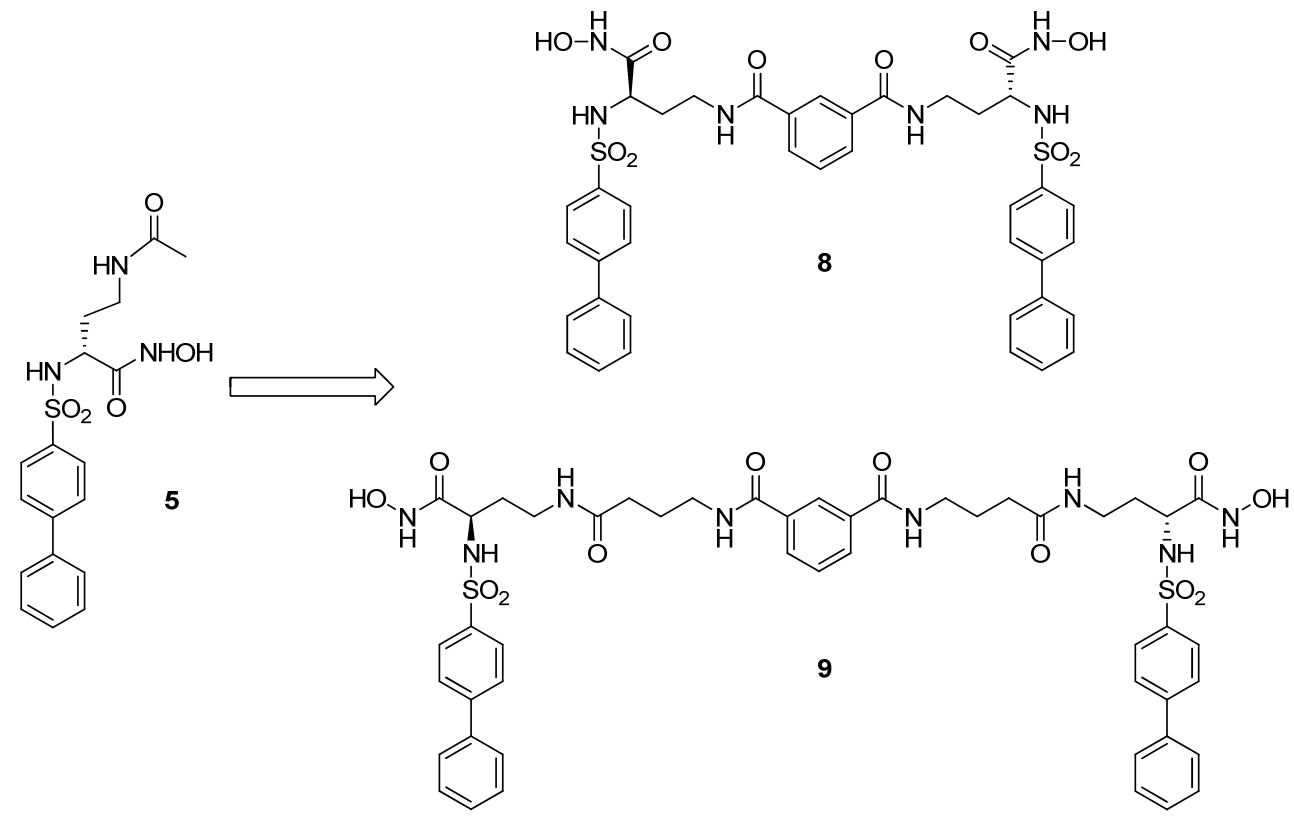

Figure 3. Structure of compound $\mathbf{5}$ and its dimeric derivatives 8 and 9. 
All new compounds were first assayed on human recombinant MMPs and then the most promising were tested on HT1080 cells to prove their ability to block MT1-MMP collagenolytic activity.

\section{Results and Discussion}

\subsection{Chemistry.}

The synthesis of the amine salt 16, key intermediate to obtain the bifunctional hydroxamates $\mathbf{6}$ and 7, is shown in Scheme 1. The tert-butyl ester $\mathbf{1 0}$ was obtained from the commercially available $(S)-(+)-\alpha-$ hydroxy-1-3-diaxo-2-isoindolinebutyric acid as previously reported. ${ }^{21}$ The secondary alcohol group of $\mathbf{1 0}$ was converted to the corresponding mesylate as a leaving group to provide $\mathbf{1 1}$ in quantitative yield. The azido derivative 12 was prepared by conversion of 11 through $\mathrm{SN} 2$ reaction $\left(\mathrm{NaN}_{3}, \mathrm{DMF}, 65^{\circ} \mathrm{C}\right)$ in high yield (98\%). Compound 12 was reduced to the corresponding amine 13 by Pd-catalyzed hydrogenation ( $92 \%$ yield) followed by sulfonylation with the commercial p-methoxy-biphenyl sulfonyl chloride affording derivative 14 (49\% yield). A further SN2 reaction of compound 14 with the commercial 2-(Boc-amino)ethyl bromide gave ester 15 (64\% yield). Finally, amine 16 was obtained as trifluoroacetate salt by selective hydrolysis of Boc group in the presence of the tert-butyl group upon treatment of compound 15 with trifluoroacetic acid (TFA) under controlled conditions $\left(4 \mathrm{~h}\right.$ at $0{ }^{\circ} \mathrm{C}$ under a nitrogen atmosphere, $56 \%$ yield).

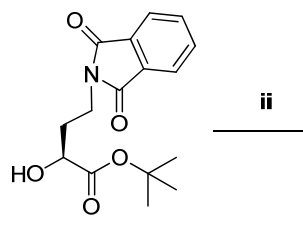

10

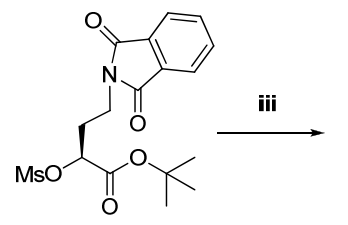

11

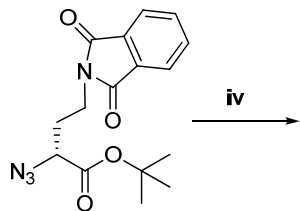

12
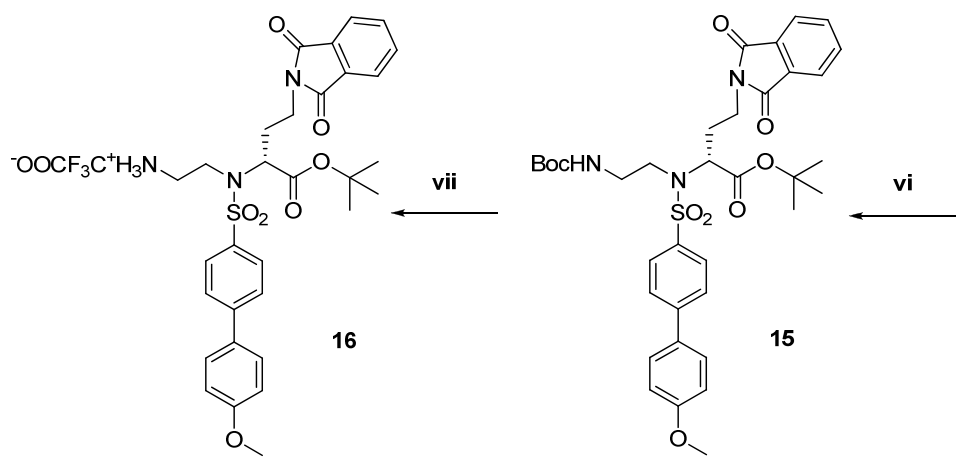
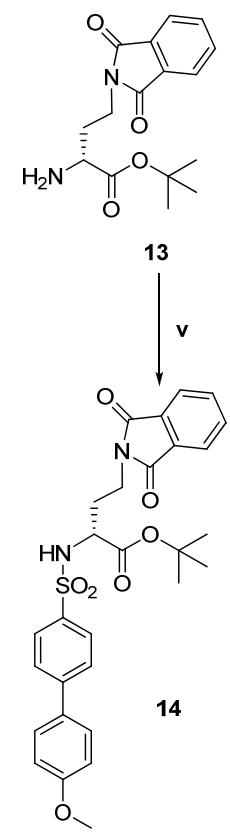
Scheme 1. Reagents and conditions: i) $\mathrm{MsCl}, \mathrm{Et} 3 \mathrm{~N}, \mathrm{DCM}, \mathrm{rt}$ (quantitative); ii) $\mathrm{NaN}_{3}, \mathrm{DMF}, 65{ }^{\circ} \mathrm{C}, 98 \%$; iii) $\mathrm{H}_{2} / \mathrm{Pd} \mathrm{MeOH}$, rt, 92\%; iv) p-methoxy-biphenylsulfonyl chloride, $\mathrm{NMM}, \mathrm{THF} / \mathrm{H} 2 \mathrm{O}, \mathrm{rt}, 49 \%$; v) 2-(Boc amino)ethylbromide, $\mathrm{K}_{2} \mathrm{CO}_{3}$, DMF, rt, $64 \%$; vi) TFA, DCM, $0^{\circ} \mathrm{C}, 4 \mathrm{~h}, 56 \%$.

The final dimeric hydroxamates 6 and 7 were synthesized as reported in Scheme 2. The di-NHS $(N-$ hydroxysuccinimido) activated esters $\mathbf{1 7 ^ { 1 5 }}$ and $\mathbf{2 1 ^ { 1 6 }}$ were added to the corresponding solution of $\mathbf{1 6}$ in DMF and in the presence of $N, N$-diisopropylethylamine (DIPEA), affording respectively the tert-butyl esters 18 (30\% yield) and 22 (25\% yield). The carboxylic acids 19 and 23 were obtained by tert-butyl group acidic cleavage with TFA. These carboxylates were converted into the corresponding hydroxamates 6 and 7 by condensation with $O$-(tetrahydro-2H-pyran-2-yl)hydroxylamine $\left(\mathrm{THPONH}_{2}\right.$ ) to give the tetrahydropyranyl intermediates $\mathbf{2 0}$ and $\mathbf{2 4}$. Subsequently, the deprotection of the hydroxamate moiety was conducted by acid hydrolysis with $\mathrm{HCl} 4 \mathrm{~N}$ affording 6 and 7 (78\% and 48\% yield).
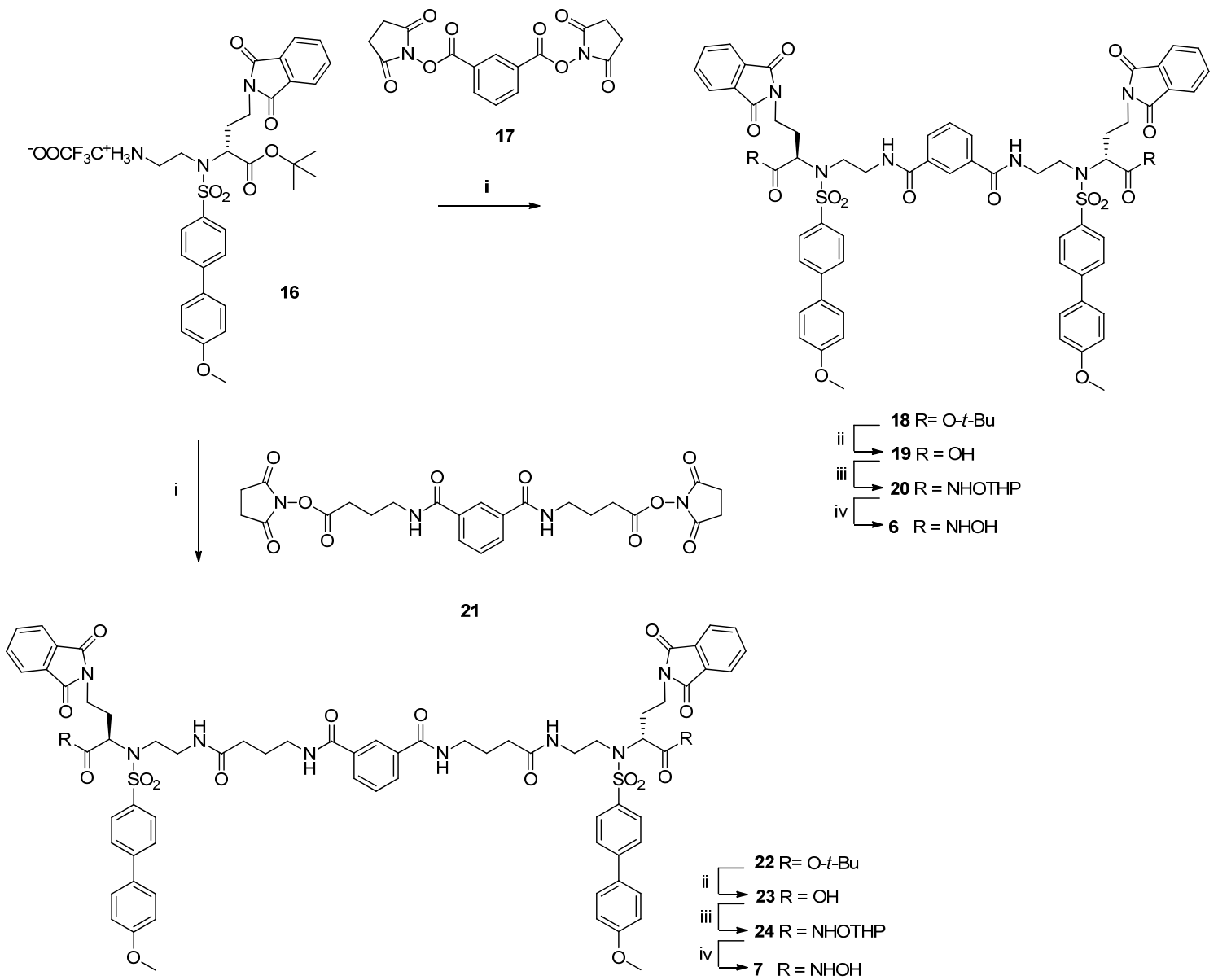
Scheme 2: Reagents and conditions: i) 17 or 21, DIPEA, DMF, rt (compound 18: 30\%, compound 22: 25\%); ii) TFA, DCM, rt, (compound 19: 86\%, compound 23 90\%; iii) THPONH2, EDC, HOBt, Et 3 N, DMF, rt; iv) $\mathrm{HCl}$ 4N, MeOH, dioxane, rt, (compound 6: 48\% from 19, compound 7: 48\% from 23).

Homodimers 8 and 9 have been synthesized following the procedure reported in Scheme 3. The reported dichloride $\mathbf{2 6}^{16}$ was added to a DMF solution of $\mathbf{2 5}^{20}$ in the presence of DIPEA to give the di-tert butyl esters $(R, R)-\mathbf{2 7}$ and $\mathbf{2 8}$, which were separated by flash chromatography. The corresponding carboxylic acids derivatives $\mathbf{2 9}$ and $\mathbf{3 0}$ were obtained by tert-butyl group cleavage with TFA. The carboxylate $\mathbf{2 9}$ was converted into the corresponding hydroxamate 8 by condensation with $O$-(tetrahydro-2H-pyran-2yl)hydroxylamine $\left(\mathrm{THPONH}_{2}\right)$ to give the tetrahydropyranyl intermediate $\mathbf{3 1}$ followed by acid hydrolysis with $\mathrm{HCl} 4 \mathrm{~N}$. The carboxylate $\mathbf{2 8}$ was converted into the corresponding hydroxamate 9 by condensation with $\mathrm{O}$-(tert-butyldimethylsilyl)hydroxylamine $\left(\mathrm{TBDMSiONH}_{2}\right)$ to give the silyl intermediates $\mathbf{3 2}$ and subsequent deprotection of the hydroxamate moiety with TFA.
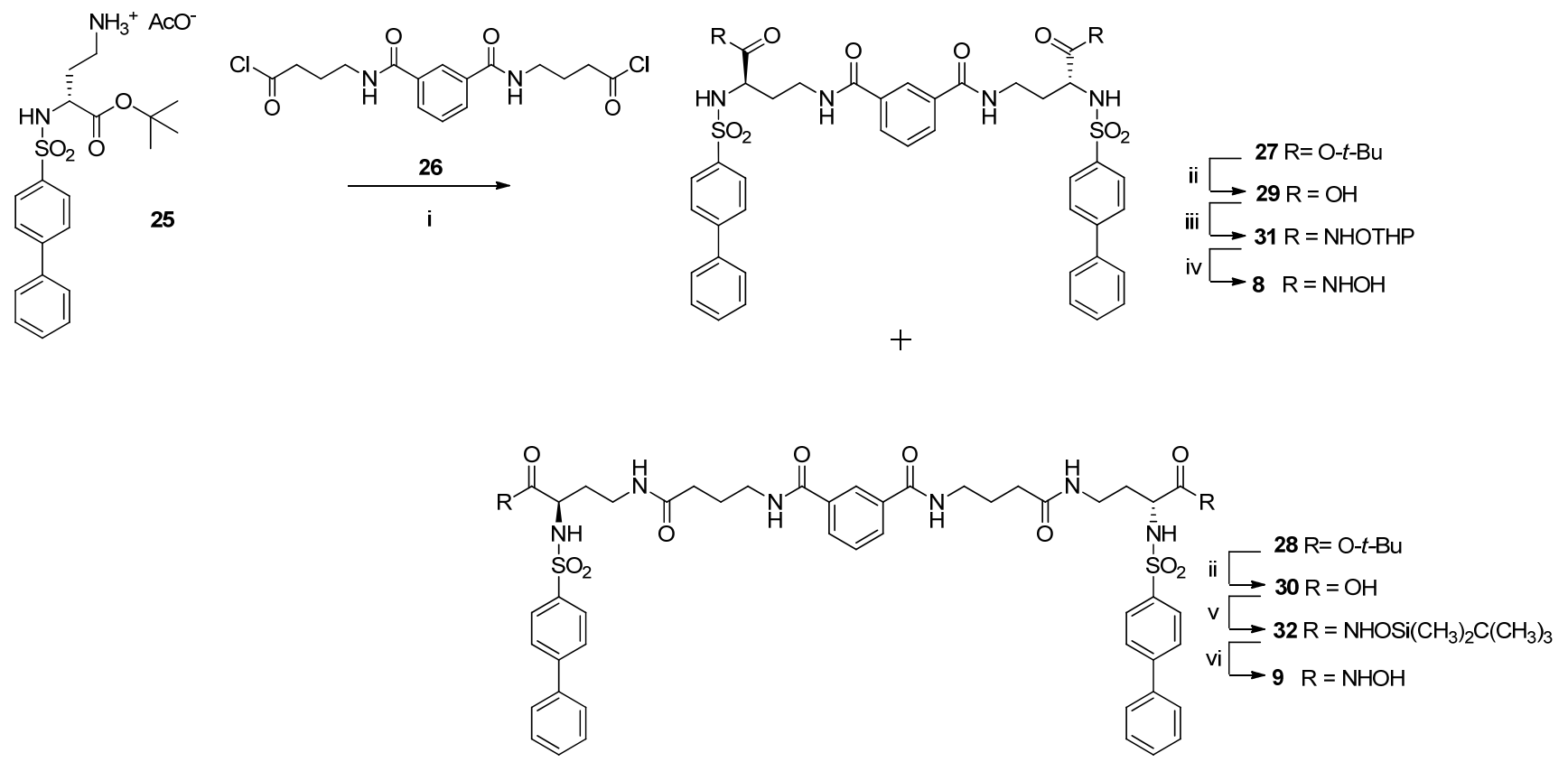

Scheme 3: Reagents and conditions: i) 26, DIPEA, DMF, rt, (compound 27: 15\%, compound 28: 23\%); ii) TFA, DCM, rt (compound 29: 86\%, compound 30: 46\%); iii) THPONH 2, EDC, HOBt, Et $3 \mathrm{~N}, \mathrm{DMF}$,

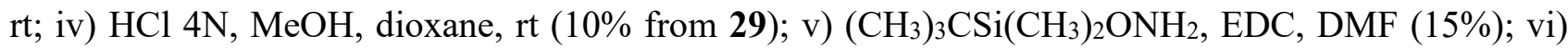
TFA, DCM (46\%). 


\subsection{Biological activity on isolated enzymes}

The newly synthesized compounds 6-9 were tested in vitro on human recombinant MT1-MMP, MMP1, MMP-2, and MMP-9 by a fluorometric assay. ${ }^{22}$ MMP-2 and MMP-9 are validated targets in cancer therapy so they are useful to investigate the selectivity profile. MMP-1 is considered an anti-target because its inhibition seems to be responsible for side effects such as musculoskeletal syndrome, clinically observed for broad spectrum MMPIs. ${ }^{23}$ Results are reported in Table 1 as IC 50 values (nM) and monomers 4 and 5 were used as reference compounds together with CGS 27023A, a well-known MMP inhibitor. Compounds 6, 7 and 8, 9 reveled a nanomolar activity towards MT1-MMP respectively comparable to 4 and 5. These data suggest that the dimerization in P1 and P2' does not substantially affect the affinity for MT1-MMP. The length of the linker does not seem to have a great impact on MT1MMP inhibitory activity as well (see 6 vs 7 and 8 vs 9). Unfortunately, these four dimeric inhibitors have not shown an improved selectivity for the target enzyme over the other MMPs tested with respect to the parent compounds.

Since compounds 8 and 9 were less active than 6 and 7 against MT1-MMP while compound 7 showed a low water solubility, probably due to the high molecular weight, we decided to perform the following cell-based studies on the hydroxamate $\mathbf{4}$ and its shorter dimeric derivative $\mathbf{6}$. In fact dimer $\mathbf{6}$ was endowed with a nanomolar activity on MT1-MMP $\left(\mathrm{IC}_{50}=14 \mathrm{nM}\right)$ and an appreciable water solubility $(>1 \mathrm{mM})$.

Table 1. In vitro ${ }^{a}$ inhibitory activity $\left(\mathrm{IC}_{50}, \mathrm{nM}\right)$ of compounds 4-9 on MMPs.

\begin{tabular}{|c|c|c|c|c|}
\hline \multirow{2}{*}{ Compd } & \multicolumn{4}{|c|}{ IC50 nM } \\
\cline { 2 - 5 } & MMP-1 & MMP-2 & MMP-9 & MT1-MMP \\
\hline $\mathbf{4}$ & 170 & 0.67 & 0.43 & 3.9 \\
\hline $\mathbf{6}$ & 150 & 13 & 14 & 14 \\
\hline $\mathbf{7}$ & 45 & 4.1 & 2.1 & 7 \\
\hline $\mathbf{5}$ & 196 & 0.70 & 8.6 & 34 \\
\hline $\mathbf{8}$ & 870 & 1.2 & 1.25 & 80 \\
\hline $\mathbf{9}$ & 155 & 1.6 & 8.7 & 41 \\
\hline CGS 27023A & 56 & 25 & 4.8 & 23 \\
\hline
\end{tabular}


${ }^{a}$ Enzymatic data are mean values for three independent experiments performed in duplicate. SD were generally within $\pm 10 \%$.

\subsection{Biological activity on cells}

\subsubsection{Monomeric compound 4 significantly decreases cell growth compared to dimeric compound} 6

To examine the potential toxicity of compounds $\mathbf{4}$ and $\mathbf{6}$, inhibitor treated HT1080 fibrosarcoma cells were subjected to MTS (3-(4,5 dimethylthiazol-2-yl)-5-(3-carboxymethoxyphenyl)2-(4-sulfophenyl)2H-tetrazolium) colorimetric assay. As shown in Figure 4, there was no significant difference comparing the optical density of the samples treated with compound 6 at any concentration and DMSO, on the other hand, compound 4 significantly decreased cell growth when applied at $50 \mu \mathrm{M}, 20 \mu \mathrm{M}$ or $10 \mu \mathrm{M}$ compared to DMSO ( $\mathrm{P}$ values were respectively $<0.001,<0.01,<0.05$, and they are shown in the graph). These data suggest a positive effect of dimerization to prevent toxicity, confirming our previous data. ${ }^{16}$

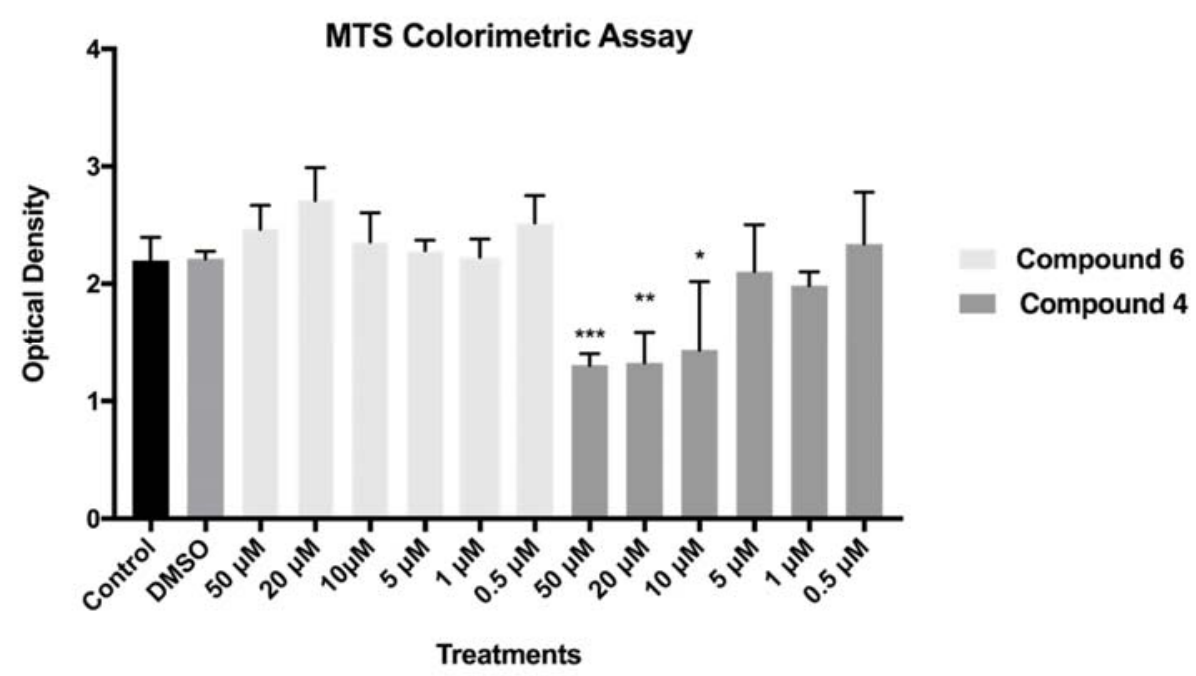

Figure 4. Toxicity evaluation of $\mathbf{4}$ and 6. HT1080 cells were incubated overnight with compounds $\mathbf{4}$ or 6 and then MTS was added to the media. Optical density was measured every hour for $4 \mathrm{~h}$ using an ELISA plate reader. Average optical densities were calculated and plotted with standard deviations (SDs) using Prism ( $\mathrm{n}=8)$. Data were compared using a one-way ANOVA followed by a Tukey's multiple correlation $(* * * \mathrm{P}<0.001, * * \mathrm{P}<0.01, * \mathrm{P}<0.05)$. 


\subsubsection{Effect of MMPIs 4 and 6 on MT1-MMP-dependent proMMP-2 activation}

Gelatin zymography was used to test compounds $\mathbf{4}$ and $\mathbf{6}$ inhibitory activity on MT1-MMP-medited proMMP-2 activation. ProMMP-2 activation is one of the major means MT1-MMP uses to promote cell invasion into basement membrane. ${ }^{24}$ We used HT1080 cells for this assay, since these cells endogenously express MT1-MMP and it has been shown that proMMP-2 activation in this cells is MT1-MMPdependent. ${ }^{8,25}$ HT1080 cells were cultured in DMEM for $24 \mathrm{~h}$ and in serum-free DMEM in the presence of GM6001, a well-known MMP inhibitor, compounds $\mathbf{4}$ or $\mathbf{6}$ at different concentrations for another 24 h. For each treatment, cells were stimulated with type I collagen, which has been shown to promote MT1MMP-mediated proMMP-2 activation. ${ }^{26}$ As shown in Figure 5, when HT1080 cells were cultured in DMEM or DMEM containing DMSO, proMMP-2 (P, $72 \mathrm{KDa})$ was effectively processed to the active form (A, $66 \mathrm{KDa})$, GM6001 abolished proMMP-2 activation except at the concentration of $0.01 \mu \mathrm{M}$ where we could detect a band corresponding to the active MMP-2. Dimer 6 seemed to prevent proMMP2 activation at the concentrations of $10 \mu \mathrm{M}$ and $1 \mu \mathrm{M}$, while it did not have any detectable effect for concentrations lower than $0.1 \mu \mathrm{M}$, on the other hand, monomer 4 inhibited proMMP-2 processing only when the concentration was $10 \mu \mathrm{M}$, since active MMP-2 could be detected in the other cases. GM6001 treatment noticeably increased the level of proMT1-MMP (65 KDa) and active MT1-MMP (55 KDa), compared to the DMSO negative control, while processed form of MT1-MMP that has lost the catalytic domain (40 KDa) was slightly decreased when GM6001 was applied at the concentrations of $10 \mu \mathrm{M}$ and $1 \mu \mathrm{M}$. Compound 6 also dose-dependently increased band intensities of proMT1-MMP and notably increased active MT1-MMP at the concentrations of $10 \mu \mathrm{M}$ or $1 \mu \mathrm{M}$, compared to the DMSO negative control while it did not affect the amount of processed MT1-MMP at any of the reported concentrations. Compound 4 did not alter the level of proMT1-MMP, the active and the processed form at any of the tested concentrations. 


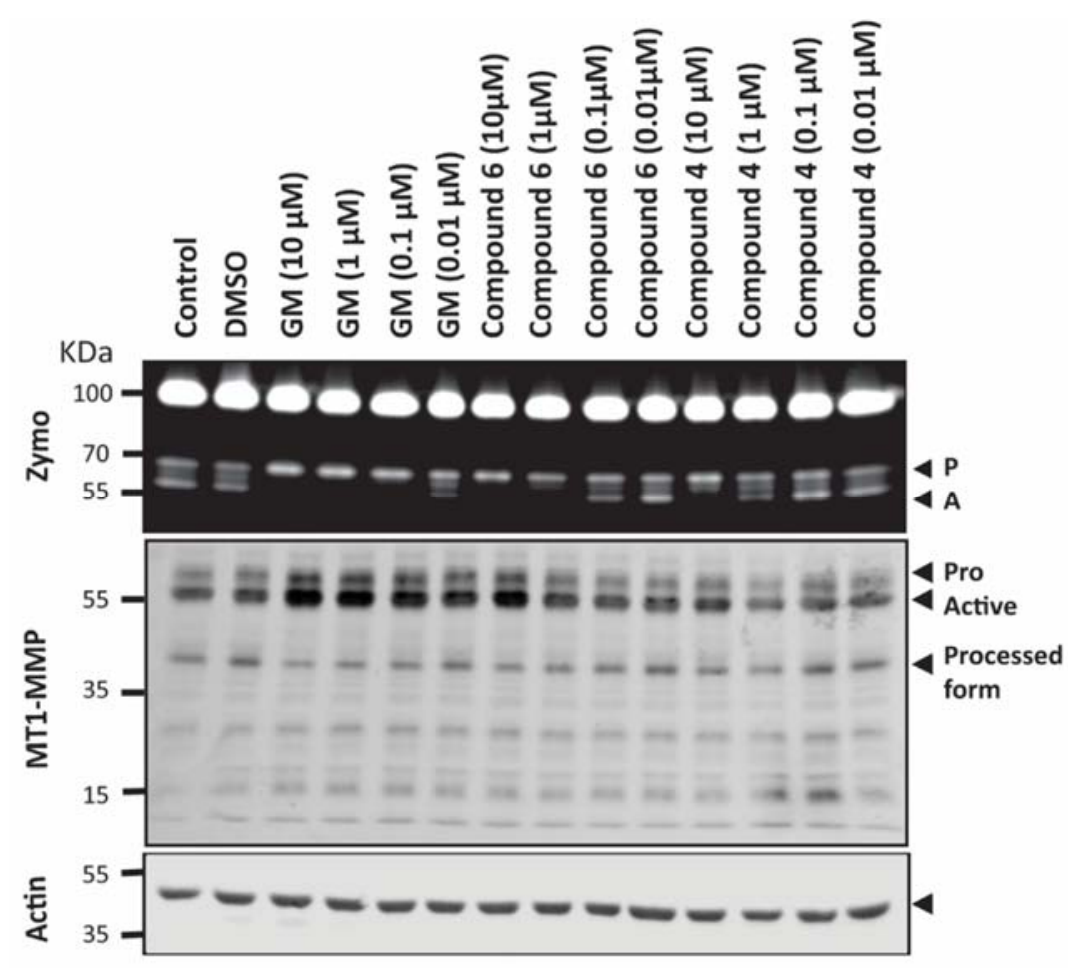

Figure 5. Effect of 4 and 6 on proMMP-2 activation. HT1080 cells were cultured for $24 \mathrm{~h}$ with collagen (Col-I, $50 \mu \mathrm{g} / \mathrm{mL}$ ) and in the presence of GM6001, compounds 4 or 6 at different concentrations. Conditioned media were collected and analyzed by zymography for proMMP-2 activation (zymo), cell lysates were subjected to WB using anti-MT1-MMP (Hpx) 222-1D8 antibody. Arrow heads point to bands of interest. $\mathrm{P}$ indicates proMMP-2, while $\mathrm{A}$ the active enzyme form. The experiments were repeated twice, and we confirmed that the data are reproducible.

\subsubsection{Effect of MMPIs 4 and 6 on collagen degradation}

To test compounds 4 and $\mathbf{6}$ inhibitory activity on MT1-MMP collagenolytic activity, a collagen film degradation assay was carried out. Again we have used HT1080 cells since they express MT1-MMP endogenously and its collagen degradation activity is MT1-MMP-dependent. ${ }^{25}$ HT1080 cells were cultured for $48 \mathrm{~h}$ on a thin collagen type-I layer in the presence of compounds 4 or $\mathbf{6}$, GM6001 and DMSO, as a negative control, after the incubation, remaining collagen was stained with Coomassie Blue. As shown in Figure 6A, cells degraded the collagen layer when treated with DMSO, while GM6001 (10 $\mu \mathrm{M})$ completely abolish MT1-MMP mediated collagen degradation. Compounds $\mathbf{6}$ and $\mathbf{4}$ seemed to completely abolish collagen degradation when they were used at the concentration of $10 \mu \mathrm{M}$, while small degradation areas could be detected when the concentration was only $1 \mu \mathrm{M}$. Collagen degradation was 
quantified measuring the integrated density of the collagen layer though ImageJ software, five pictures, corresponding to five different areas of the same sample, were quantified for each treatment. Average integrated densities were calculated and plotted with error bars, referring to the standard deviations (SDs). As shown in Figure 6B, collagen degradation was significantly decreased for all the treatments, in comparison to the DMSO control $(* * * * \mathrm{P}<0.0001$, shown in the graph), significant difference could not be detected comparing the two tested concentrations of compound $\mathbf{6}$, while there was statistical difference between applying $10 \mu \mathrm{M}$ or $1 \mu \mathrm{M}$ of compound 4 ( $\mathrm{P}<0.001$, not shown in the graph).
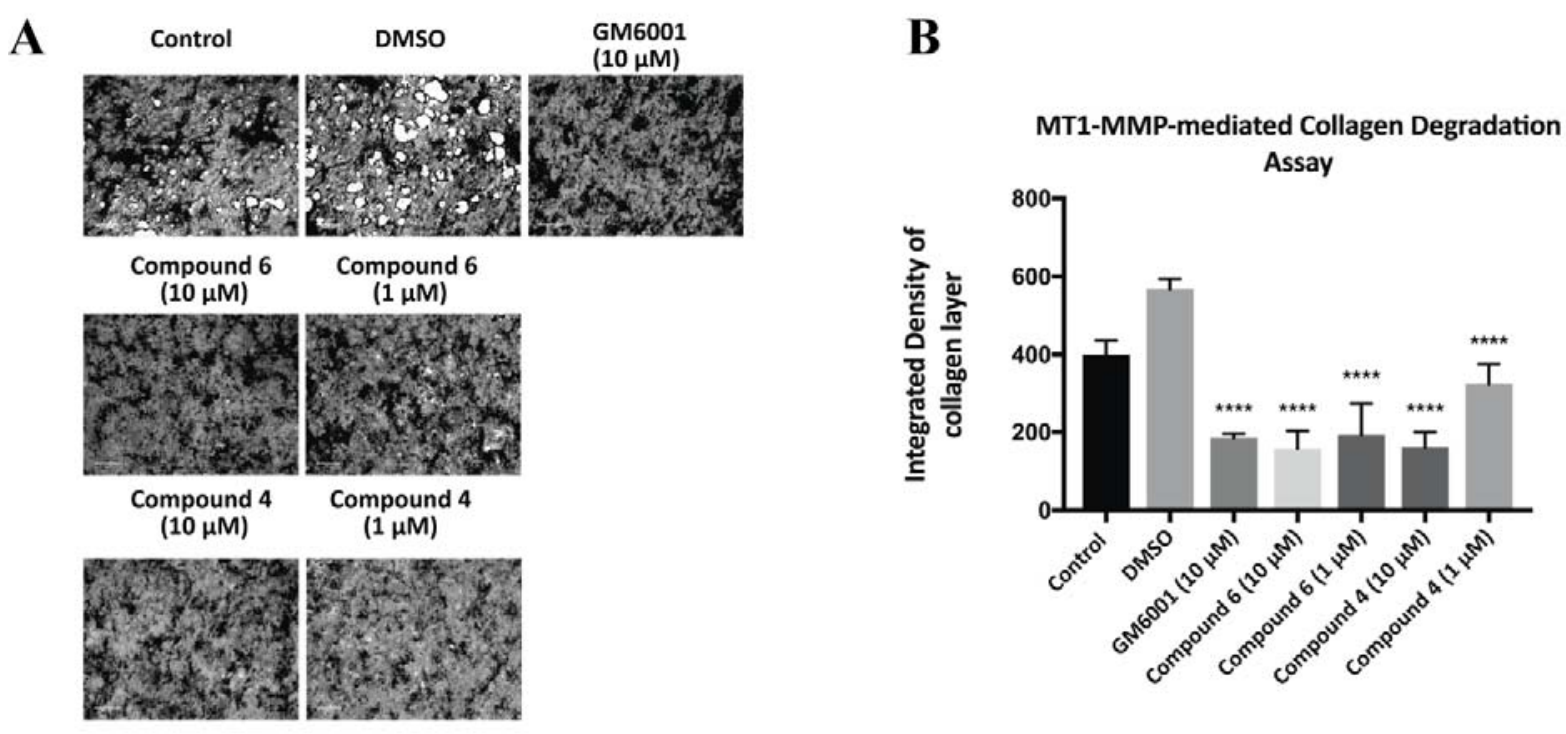

Figure 6. Effect of 4 and 6 on collagen degradation. A) HT1080 cells were subjected to collagen film degradation assay in the presence of GM6001, compounds 4 or $\mathbf{6}$ at different concentrations. Representative images are shown. Collagen is grey and degraded areas are white. Scale bars are $150 \mu \mathrm{m}$. B) Collagen degradation was quantified using ImageJ software on 5 representative areas of collagen film in each treatment $(n=5)$. Mean values \pm SD were plotted for each treatment. Each mean integrated density was compared to the negative control (DMSO) using a one-way ANOVA test, $* * * * \mathrm{P}<0.0001$. Experiments are repeated twice and the data are confirmed to be reproducible.

\subsubsection{Effect of MMPIs 4 and 6 on MT1-MMP-dependent collagen invasion}

To investigate activity of compounds $\mathbf{4}$ and $\mathbf{6}$ on MT1-MMP-dependent collagen invasion, a microcarriers beads invasion assay was employed. We have previously shown that HT1080 cells invade into collagen matrix in MT1-MMP-dependent manner. ${ }^{25}$ Once HT1080 cells were attached to gelatin- 
coated microcarrier beads, the beads/cells were suspended in a type-I collagen matrix and they were cultured overnight. Cells migrated out from the bead surface into the collagen matrix and representative pictures are shown in Figure 7A. Migrated distance of 50 cells per treatment was measured using ImageJ software and average migrated distances were plotted with red error bars (showing \pm SDs) with Prism (Figure 7B). All the treatments diminished significantly MT1-MMP dependent collagen invasion compared to DMSO $(* * * * \mathrm{P}<0.0001$, shown in the graph). Collagen invasion was not significantly different when compared the two tested concentrations of inhibitor $\mathbf{6}$ while cells migrated significantly more upon exposure to $1 \mu \mathrm{M}$ than to $10 \mu \mathrm{M}$ of compound 4 ( $\mathrm{P}<0.001$, not shown in the graph). MT1MMP-dependent invasion was statistically inhibited more when cells were incubated with $10 \mu \mathrm{M}$ of compound 6 than $10 \mu \mathrm{M}$ of compound 4 ( $\mathrm{P}<0.01$, not shown) and the same was observed comparing the $1 \mu \mathrm{M}$ concentrations of the two compounds ( $\mathrm{P}<0.00001$, not shown). It has been shown that MT1MMP is the only MMP that is capable of promoting cellular invasion within $3 \mathrm{D}$ collagen matrix. ${ }^{27}$ Thus, this difference in inhibitory activity reflects effectiveness of the dimeric compound $\mathbf{6}$ to inhibit MT1MMP on the cell surface.
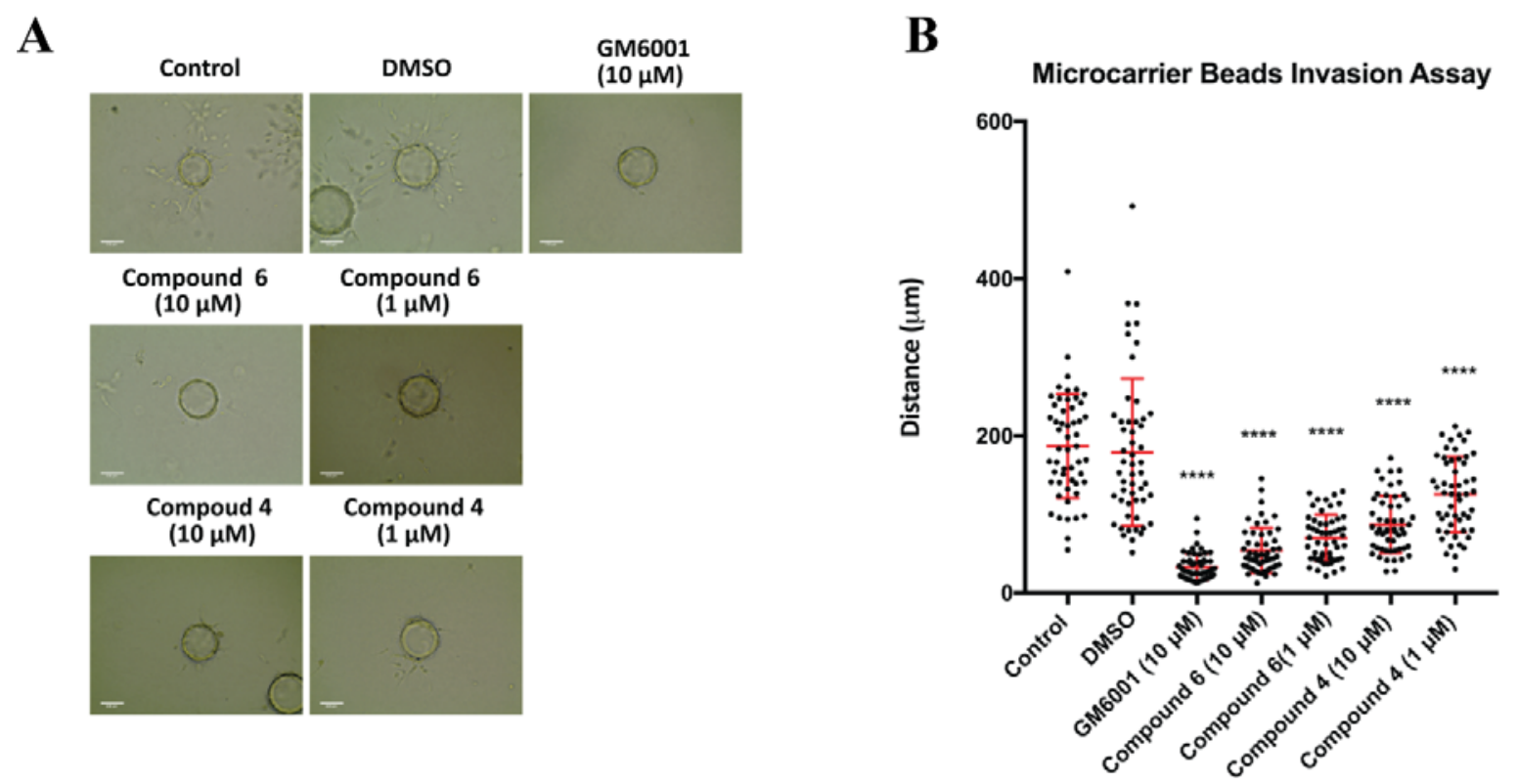

Figure 7. Effect of 4 and 6 on collagen invasion. A) HT1080 cells were subjected to a microcarrier bead invasion assay in the presence of GM6001, compounds 4 or $\mathbf{6}$. A representative image of cells migrating out from the bead surface is shown for each treatment. Scare bars are $150 \mu \mathrm{m}$. B) Quantitative analysis of microcarrier bead invasion assay: migratory distance was measured for 50 cells per treatment $(\mathrm{n}=50)$, using ImageJ software (see methods) and mean migratory distances were plotted using Prism 
software. Each mean migratory distance was compared to the negative control (DMSO) using a one-way ANOVA test, $* * * * \mathrm{P}<0.0001$. Experiments are repeated twice and the data are confirmed to be reproducible.

Considering these data we can hypothesize a mechanism of action of dimeric MT1-inhibitor $\mathbf{6}$ on tumor cell surface that explains the differences found between enzymatic assays and cell-based assays. When compounds 4 and $\mathbf{6}$ were compared using catalytic domain of MT1-MMP (enzymatic assay), 6 showed a slightly lower inhibitory activity (higher $\mathrm{IC}_{50}$ ) as shown in Table 1 . Under these assay conditions, the catalytic domain does not have any restriction and is soluble in the assay solution. On the other hand, when the effects of these inhibitors on the cell surface were compared, compound $\mathbf{6}$ had a slightly higher inhibitory activity (Figure 5, 6, and 7). ProMMP-2 activation, collagen degradation and collagen invasion in HT1080 cells are all dependent on dimerization of MT1-MMP on the cell surface, and it is possible that the distance of two catalytic domains within dimeric MT1-MMP is similar to the distance of two zinc binding groups within dimeric compound $\mathbf{6}$, and this provides steric advantage to $\mathbf{6}$ with respect to monomer 4. A molecular modeling study was performed to support this hypothesis.

\subsection{Molecular modeling}

In order to provide a possible binding disposition of compound $\mathbf{6}$, a hypothetical dimeric complex of two MT1-MMP catalytic domains has been developed. The crystallographic structure of the MMP-9 dimer in complex with a bifunctional inhibitor (PDB id: $4 \mathrm{H} 82)^{28}$ was used as a template for generating a MT1MMP dimeric structure. This structure was then used as a starting point for $50 \mathrm{~ns}$ of molecular dynamic (MD) simulation. Compound $\mathbf{6}$ was thus docked into the resulting dimer and the best ranked solution was taken into account. The corresponding MT1-MMP-6-MT1-MMP trimer thus obtained was subjected to $100 \mathrm{~ns}$ of MD simulation. As shown in Figure 8, the geometry of the ligand is in an agreement with the possible interaction within this dimeric structure, with both 4-methoxybiphenyl moieties that are inserted in the S1' cavity and the two hydroxamic acid groups able to chelate the zinc ions that show a trigonal bipyramidal chelation geometry. Interestingly, each of the two phthalimidic groups shows lipophilic interactions with both MT1-MMP chains, reducing their exposition to water. 


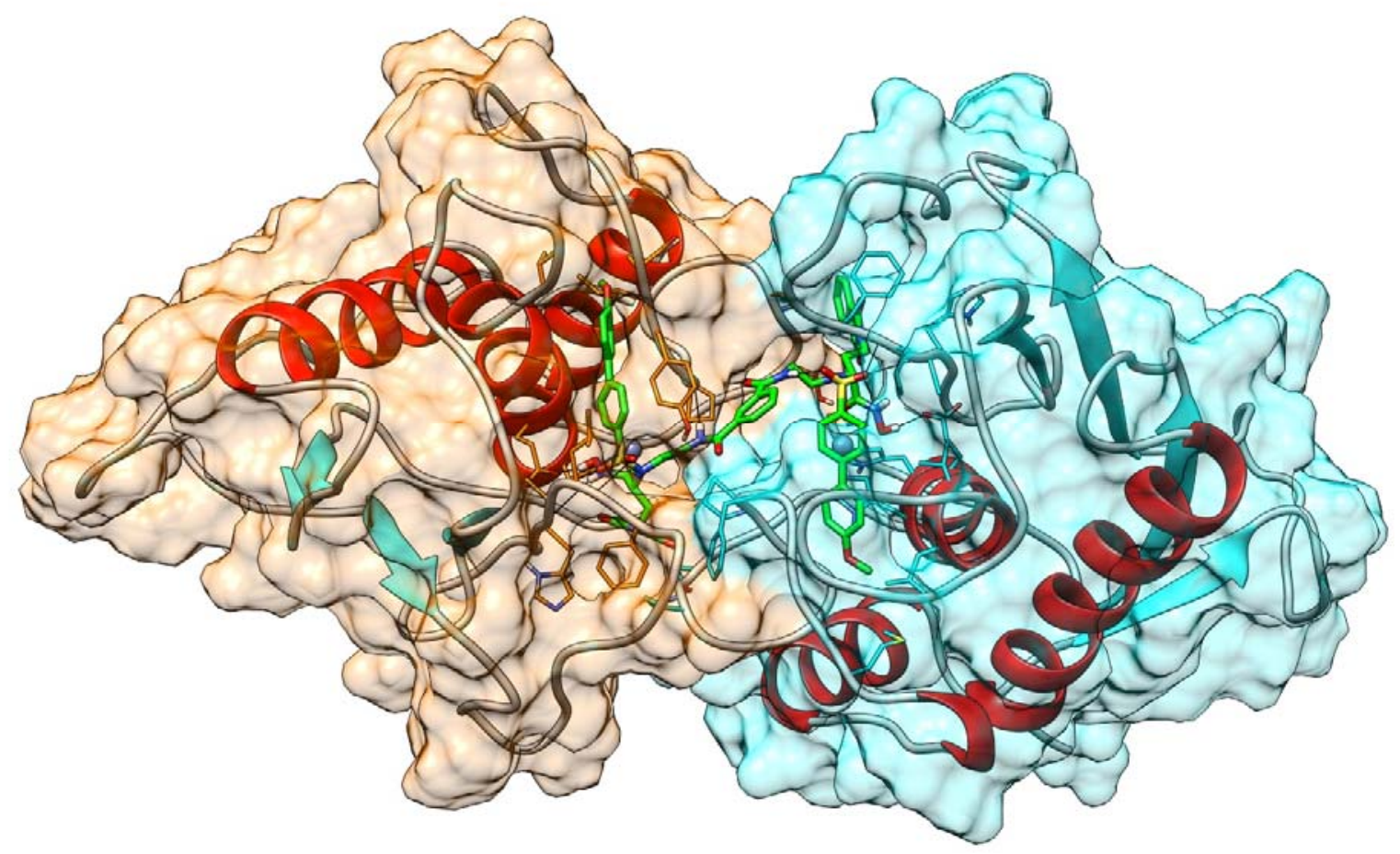

Figure 8. Proposed trimeric adduct MT1-MMP-6-MT1-MMP (catalytic domains).

\section{Conclusions}

In the present study we reported the design and synthesis of the first bifunctional MT1-MMP inhibitors, compounds 6-9, potentially able to impair MT1-MMP homodimerization on tumor cell surface. These were symmetrical homodimers derived from previously described monomeric arylsulfonamide hydroxamate-based MMP inhibitors, characterized by different linker lengths and branch points. Among these compounds, a promising derivative, $\mathbf{6}$, was identified by fluorometric assay on human recombinant MMPs and was selected for further studies on HT1080 fibrosarcoma cell line. Dimer 6 was a nanomolar inhibitor of MT1-MMP ( $\left.\mathrm{IC}_{50}=14 \mathrm{nM}\right)$ and also of MMP-2 and MMP-9, widely known as targets in cancer therapy. Moreover 6 showed a lower cell cytotoxicity (by MTS assay up to $50 \mu \mathrm{M}$ ) with respect to its monomeric analogue, compound $\mathbf{4}$, indicating that dimerization can have a positive effect to prevent compounds toxicity. To prove the collagenolytic activity of dimer 6 with respect to 4 , they were tested on HT1080 cells that express endogenous MT1-MMP. Both compounds reduced MT1-MMP-dependent proMMP-2 activation, collagen degradation and collagen invasion in a dose-dependent manner but dimer 6 showed a higher potency in all assays. In particular, 6 prevented proMMP-2 activation already at the concentration of $1 \mu \mathrm{M}$, completely abolished collagen degradation at the concentration of $10 \mu \mathrm{M}$ and 
diminished significantly MT1-MMP dependent collagen invasion at $10 \mu \mathrm{M}$ concentration. Finally, a theoretical model of compound 6 binding to dimeric MT1-MMP (catalytic domains) have been proposed. Taken together, our preliminary results supported the use of dimeric inhibitors as alternative approach to reduce cancer cell invasion by inhibiting dimeric MT1-MMP. Further studies will be necessary to improve dimer 6 selectivity for MT1-MMP and to fully demonstrate the binding mode and mechanism of action of dimeric MT1-inhibitors on tumor cell surface.

\section{Materials and methods}

\subsection{Chemistry}

Melting points were determined on a Kofler hotstage apparatus and are uncorrected. ${ }^{1} \mathrm{H}$ and ${ }^{13} \mathrm{C}$ NMR spectra were recorded on a Bruker Avance III HD $400 \mathrm{MHz}$ spectrometer. Chemical shifts $(\delta)$ are reported in parts per million and coupling constants $(J)$ are reported in hertz $(\mathrm{Hz}) .{ }^{13} \mathrm{C}$ NMR spectra were fully decoupled. The following abbreviations were used to explain molteplicities: singlet (s), doublet (d), triplet ( $\mathrm{t}$ ), double doublet (dd), broad (br), and multiplet (m). Chromatographic separations were performed on silica gel columns by flash column chromatography (Kieselgel 40, 0.040-0.063 mm, Merck) or using ISOLUTE Flash Si II cartridges (Biotage). Reactions were followed by thin-layer chromatography (TLC) on Merck aluminum silica gel (60 F254) sheets that were visualized under a UV lamp, and hydroxamic acids were visualized with $\mathrm{FeCl}_{3}$ aqueous solution. Evaporation was performed in vacuo (rotating evaporator). Sodium sulfate was always used as the drying agent. Commercially available chemicals were purchased from Sigma-Aldrich. Elemental analysis was used to determine the purity of target compounds. Analytical results are within $\pm 0.40 \%$ of the theoretical values. CGS 27023A was synthesized as previously described. ${ }^{29}$

\subsection{1 (S)-tert-butyl 4-(1,3-dioxoisoindolin-2-yl)-2-((methylsulfonyl)oxy)butanoate (11)}

To a solution of 10 $\mathbf{1 0}^{16,21}(210 \mathrm{mg}, 0.687 \mathrm{mmol})$ in DCM $(5 \mathrm{~mL})$ and $\mathrm{Et}_{3} \mathrm{~N}(190 \mu \mathrm{L}), \mathrm{MsCl}$ was added dropwise. The solution was stirred for $1.5 \mathrm{~h}$ at rt. The reaction mixture was dissolved in DCM and washed $(3 \times 15 \mathrm{~mL})$ with water. The combined organic phases were dried over $\mathrm{Na}_{2} \mathrm{SO}_{4}$ and evaporated under reduced pressure. The mesylate $\mathbf{1 1}$ was obtained as a pure colorless oil (261 mg, quantitative yield). ${ }^{1} \mathrm{H}$ NMR (400 MHz, $\left.\mathrm{CDCl}_{3}\right): \delta 7.86(\mathrm{~m}, 2 \mathrm{H}, \mathrm{Ar}), 7.71(\mathrm{~m}, 2 \mathrm{H}, \mathrm{Ar}), 4.95\left(\mathrm{dd}, J_{1}=4.4 \mathrm{~Hz}, J_{2}=8 \mathrm{~Hz}, 1 \mathrm{H}\right)$, 3.90-3.79 (m, 2H), $3.21(\mathrm{~s}, 3 \mathrm{H}), 2.38-2.08(\mathrm{~m}, 2 \mathrm{H}), 1.49$ (s, 9H). Elemental Analysis for $\mathrm{C}_{17} \mathrm{H}_{21} \mathrm{NO}_{7} \mathrm{~S}$ calculated: \% C, 53.25; \% H, 5.52; \% N 3.65; found: \% C, 53.30; \% H, 5.67; \% 3.71. 


\subsection{2 (R)-tert-butyl 2-azido-4-(1,3-dioxoisoindolin-2-yl)butanoate (12)}

To a solution of the mesylate 11 (732 mg, $1.90 \mathrm{mmol})$ in $4.7 \mathrm{~mL}$ of DMF, sodium azide (744 $\mathrm{mg}, 11.45$ mmol) was added and the mixture was stirred overnight at $65{ }^{\circ} \mathrm{C}$. The solvent was removed and the residue was dissolved in EtOAc and washed with water $(3 \times 20 \mathrm{~mL})$. The organic phase was dried over $\mathrm{Na}_{2} \mathrm{SO}_{4}$ and evaporated under reduced pressure. The azido derivative $\mathbf{1 2}$ was isolated pure as white solid (622 mg, 98\% yield) without further purifications. ${ }^{1} \mathrm{H}$ NMR (400 MHz, $\left.\mathrm{CDCl}_{3}\right): \delta 7.86(\mathrm{~m}, 2 \mathrm{H}, \mathrm{Ar}), 7.73$ (m, 2H, Ar), 3.87-3.81 (m, 3H), 2.21-2.12 (m, 1H), 2.04-2.00 (m, 1H), 1.50 (s, 9H). Elemental Analysis for $\mathrm{C}_{16} \mathrm{H}_{18} \mathrm{~N}_{4} \mathrm{O}_{4}$ calculated: \% C, 58.17; \% H, 5.49; \% N 16.96; found: \% C, 58.22; \% H, 5.53; \% N 16.99 .

\subsection{3 (R)-tert-butyl 2-amino-4-(1,3-dioxoisoindolin-2-yl)butanoate (13)}

Compound 12 (600 mg, $1.81 \mathrm{mmol})$ was dissolved in $\mathrm{MeOH}(10 \mathrm{~mL})$ and the solution was stirred under hydrogen atmosphere in the presence of $10 \% \mathrm{Pd}-\mathrm{C}(575 \mathrm{mg})$ overnight. The resulting mixture was filtered on celite and the filtrate was evaporated under reduced pressure to give the deprotected salt $\mathbf{1 3}$ (507 mg, 92\% yield). ${ }^{1} \mathrm{H}-\mathrm{NMR}\left(400 \mathrm{MHz}, \mathrm{DMSO}-\mathrm{d}_{6}\right): \delta$ 7.87-7.81 (m, 4H, Ar), 3.69-3.65 (t, J= $8 \mathrm{~Hz}$, $1 \mathrm{H}), 3.26-3.24(\mathrm{~m}, 2 \mathrm{H}), 1.89-1.98(\mathrm{~m}, 1 \mathrm{H}), 1.77-1.65(\mathrm{~m}, 1 \mathrm{H}), 1.38(\mathrm{~s}, 9 \mathrm{H})$. Elemental Analysis for $\mathrm{C}_{16} \mathrm{H}_{20} \mathrm{~N}_{2} \mathrm{O}_{4}$ calculated: \% C, 63.14; \% H, 6.62; \% N 9.20; found: \% C, 63.24; \% H, 6.78; \% N 9.31.

\subsection{4 (R)-tert-butyl 4-(1,3-dioxoisoindolin-2-yl)-2-(4'-methoxy-[1,1'-biphenyl]-4- ylsulfonamido)butanoate (14)}

To a solution of amine $13(500 \mathrm{mg}, 1.64 \mathrm{mmol})$ in dry THF, $N$-methylmorpholine $(0.36 \mathrm{~mL})$ and 4methoxy-biphenylsulforylchloride $(557 \mathrm{mg}, 1.97 \mathrm{mmol})$ were added under nitrogen atmosphere. The solution was stirred at $\mathrm{rt}$ for $48 \mathrm{~h}$ and then the solvent was removed. The residue was dissolved in EtOAc, washed $(3 \times 15 \mathrm{~mL})$ with water, dried over $\mathrm{Na}_{2} \mathrm{SO}_{4}$ and evaporated. The crude was purified by flash chromatography (in gradient from $n$-hexane/EtOAc 6:1 to only EtOAc) to give 14 (440 mg, 45\% yield) as white solid. ${ }^{1} \mathrm{H}-\mathrm{NMR}\left(400 \mathrm{MHz}, \mathrm{CDCl}_{3}\right): \delta$ 7.89-7.81(m, 4H, Ar), 7.72-7.68 (m, 2H, Ar), 7.65-7.62 (m, 2H, Ar), 7.52-7.49 (m, 2H, Ar), 7.00-6.98 ( m, 2H, Ar), 5.48 (d, J=9.2 Hz, 1H), 3.97-3.90 (m, 1H), $3.88(\mathrm{~s}, 3 \mathrm{H}), 3.79-3.74(\mathrm{~m}, 1 \mathrm{H}), 2.29-2.15(\mathrm{~m}, 2 \mathrm{H}), 1.17(\mathrm{~s}, 9 \mathrm{H})$. Elemental Analysis for $\mathrm{C}_{29} \mathrm{H}_{30} \mathrm{~N}_{2} \mathrm{O}_{7} \mathrm{~S}$ calculated: \% C, 63.26; \% H, 5.49; \% N 5.09; found: \% C, 63.34; \% H, 5.62; \% N 5.22.

\subsection{5 (R)-tert-butyl 2-(N-(2-((tert-butoxycarbonyl)amino)ethyl)-4'-methoxy-[1,1'- biphenyl]-4-ylsulfonamido)-4-(1,3-dioxoisoindolin-2-yl)butanoate (15)}

To a solution of sulfonamide $14(250 \mathrm{mg}, 0.45 \mathrm{mmol})$ in dry DMF $(6.85 \mathrm{~mL}), \mathrm{K}_{2} \mathrm{CO}_{3}(627 \mathrm{mg}, 4.54$ $\mathrm{mmol}$ ) and 2-(Boc amino) ethylbromide (104 mg, $0.68 \mathrm{mmol})$ were added under Argon atmosphere. The 
solution was stirred at $\mathrm{rt}$ for $48 \mathrm{~h}$, then the solvent was removed. The residue was dissolved in EtOAc and washed $(2 \times 15 \mathrm{~mL})$ with water, dried over $\mathrm{Na}_{2} \mathrm{SO}_{4}$ and evaporated under reduced pressure. The crude was purified by flash chromatography using Isolute Si II cartridge (n-hexane/EtOAc 5:1) to give 15 (203 $\mathrm{mg}, 63 \%$ yield) as white solid. ${ }^{1} \mathrm{H}-\mathrm{NMR}\left(400 \mathrm{MHz}, \mathrm{CDCl}_{3}\right): \delta$ 7.91-7.81 (m, 4H, Ar), 7.74-7.69 (m, 2H, Ar), 7.64 (m, 2H, Ar), 7.52 (m, 2H, Ar), 6.99 (m, 2H, Ar), 5.47-5.43 (m, 1H), 4.52-4.50 (m, 1H), 3.86$3.77(\mathrm{~m}, 2 \mathrm{H}), 3.86(\mathrm{~s}, 3 \mathrm{H}), 3.48-3.53(\mathrm{~m}, 2 \mathrm{H}), 3.31-3.25(\mathrm{~m}, 1 \mathrm{H}), 2.36-2.26(\mathrm{~m}, 1 \mathrm{H}), 2.04-1.98(\mathrm{~m}, 2 \mathrm{H})$, 1.37 (s, 9H), 1.27 (s, 9H). Elemental Analysis for $\mathrm{C}_{36} \mathrm{H}_{43} \mathrm{~N}_{3} \mathrm{O}_{9} \mathrm{~S}$ calculated: \% C, 62.32; \% H, 6.25; \% N 6.06; found: \% C, 62.47; \% H, 6.38; \% N 6.23.

\subsection{6 (R)-tert-butyl-4'-methoxy-[1,1'-biphenyl]-4-ylsulfonamido)-4-(1,3-dioxoisoindolin-}

\section{2-yl)butanoate ethyl ammonium salt (16)}

Trifluoroacetic acid (TFA) $(0.91 \mathrm{~mL}, 11.87 \mathrm{mmol})$ was added dropwise, under argon atmosphere, to a stirred solution of tert-butyl ester $15(275 \mathrm{mg}, 0.39 \mathrm{mmol})$ in dry DCM $(4.37 \mathrm{~mL})$ cooled to $0{ }^{\circ} \mathrm{C}$. The solution was stirred for $3 \mathrm{~h}$ at $0{ }^{\circ} \mathrm{C}$ and then the solvent was removed in vacuum. The residue was coevaporated $(3 \times 10 \mathrm{~mL})$ with a mixture of toluene and DCM. The crude product was purified by flash chromatography $\left(\mathrm{CHCl}_{3} / \mathrm{MeOH}\right.$ 40:1) using Isolute Flash Si II cartridge $5 \mathrm{~g}$ to yield $\mathbf{1 6}$ as a white solid (117 mg, 56\% yield). ${ }^{1} \mathrm{H}-\mathrm{NMR}\left(400 \mathrm{MHz}, \mathrm{CDCl}_{3}\right.$ ): $\delta 8.14$ (brs, 3H), 7.90-7.82 (m, 4H, Ar), 7.72-7.69 (m, 4H, Ar), 7.53 (m, 2H, Ar), 6.99 (m, 2H, Ar), 4.50 (dd, $\left.J_{1}=4.4 \mathrm{~Hz}, J_{2}=10.4 \mathrm{~Hz}, 1 \mathrm{H}\right), 3.86(\mathrm{~s}, 3 \mathrm{H})$, 3.78-3.66 (m, 4H), 3.57-3.45 (m, 3H), 2.37-2.28 (m, 1H), 2.00-1.96 (m, 1H), $1.39(\mathrm{~s}, 9 \mathrm{H}) .{ }^{19} \mathrm{~F}-\mathrm{NMR}$ (376.46 MHz, $\mathrm{CDCl}_{3}$ ): $\delta$-75.81. Elemental Analysis for $\mathrm{C}_{33} \mathrm{H}_{36} \mathrm{~F}_{3} \mathrm{~N}_{3} \mathrm{O}_{9} \mathrm{~S}$ calculated: \% C, 56.00; \% $\mathrm{H}$, 5.13 ; \% N 5.94; found: \% C, 56.28; \% H, 5.28; \% N 5.19.

\subsubsection{General procedure for the preparation of dimeric di-tert-butyl esters 18 and 22.}

A solution of the suitable $N H S$ ester $(1 \mathrm{eq})$ and $N, N$ diisopropylethylamine $(60 \mu \mathrm{L}, 6 \mathrm{eq})$ in dry DMF $(1.5 \mathrm{~mL})$ was slowly added to a solution of the amine salt $16(2.5 \mathrm{eq})$ in dry DMF $(1.0 \mathrm{~mL})$ cooled to 0 ${ }^{\circ} \mathrm{C}$ under Argon atmosphere. The resulting solution was stirred overnight at $\mathrm{rt}$ and then the solvent was removed in vacuum.

\subsubsection{Dimeric di-tert-butyl ester 18}

The title compound was prepared from NHS ester $17(32 \mathrm{mg}, 0.09 \mathrm{mmol})$ and the amine salt $16(129 \mathrm{mg}$, $0.18 \mathrm{mmol}$ ) following the general procedure. The crude product was purified by flash chromatography $\left(\mathrm{CHCl}_{3}\right)$ using Isolute $\mathrm{Si}$ II cartridge to afford the di-tert-butyl ester $\mathbf{1 8}$ as a colorless oil $(60 \mathrm{mg}, 30 \%$ yield). ${ }^{1} \mathrm{H}-\mathrm{NMR}\left(400 \mathrm{MHz}, \mathrm{CDCl}_{3}\right): \delta 8.34$ (brs, $\left.1 \mathrm{H}\right), 7.95$ (m, 2H, Ar), 7.84-7.80 (m, 8H, Ar), 7.72-7.68 
(m, 4H, Ar), 7.58-7.56 (m, 4H, Ar), 7.47-7.39 (m, 5H, Ar), 6.96 (m, 4H, Ar), 4.55 (dd, $J_{1}=5.6 \mathrm{~Hz}, J_{2}=$ $9.2 \mathrm{~Hz}, 2 \mathrm{H}), 3.85(\mathrm{~s}, 6 \mathrm{H}), 3.85-3.53(\mathrm{~m}, 12 \mathrm{H}), 2.41-2.32(\mathrm{~m}, 2 \mathrm{H}), 2.11-2.01(\mathrm{~m}, 2 \mathrm{H}), 1.29(\mathrm{~s}, 18 \mathrm{H}) .{ }^{13} \mathrm{C}-$ NMR (100 MHz, $\left.\mathrm{CDCl}_{3}\right): \delta 169.2(2 \times \mathrm{COO}), 168.2(2 \times \mathrm{CON}), 167.1(2 \times \mathrm{CONH}), 160.0\left(\mathrm{Ar}-\mathrm{C}-\mathrm{OCH}_{3}\right)$, 145.3 (Ar-C-SO 2 ), 137.0, 134.5, 132.0, 131.5, (Ar-C), 134.01, 130.3, 128.4, 128.0, 127.0, 123.4, 114.4 (Ar-CH), $83.0\left(\mathrm{C}\left(\mathrm{CH}_{3}\right)_{3}\right), 58.9\left(\mathrm{CHNSO}_{2}\right), 55.4\left(\mathrm{OCH}_{3}\right), 45.3\left(\mathrm{CH}_{2} \mathrm{NSO}_{2}\right), 40.5\left(\mathrm{CH}_{2} \mathrm{NHCO}\right), 35.5$

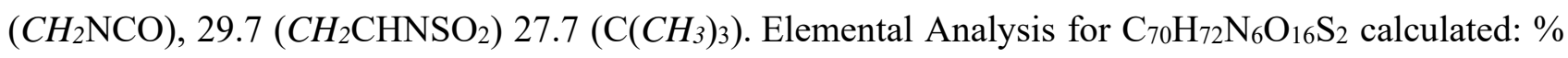
C, 63.81; \% H, 5.51; \% N 6.38; found: \% C, 63.96; \% H, 5.67; \% N 6.69.

\subsubsection{Dimeric di-tert-butyl ester 22}

The title compound was prepared from NHS ester $21(31.48 \mathrm{mg}, 0.0593 \mathrm{mmol})$ and the amine salt 16 (105 $\mathrm{mg}, 0.15 \mathrm{mmol}$ ) following the general procedure. The crude product was purified by flash chromatography $\left(\mathrm{CHCl}_{3} / \mathrm{MeOH} 20: 1\right)$ to give the di-tert-butyl ester 22 as a colorless oil (54 $\mathrm{mg}, 25 \%$ yield). ${ }^{1} \mathrm{H}-\mathrm{NMR}\left(400 \mathrm{MHz}, \mathrm{CDCl}_{3}\right): \delta 8.25$ (brs, 1H), 7.97 (m, 2H, Ar), 7.80-7.43 (m,8H, Ar), 7.69-7.66 (m, 4H, Ar), 7.62-7.57 (m, 6H, Ar), 7.49 (m, 4H, Ar), 7.42 (m, 1H, Ar), 7.20 (brs, 1H), 6.97 (m, 4H, Ar), $4.51\left(\mathrm{dd}, J_{1}=5.6 \mathrm{~Hz}, J_{2}=9.6 \mathrm{~Hz}, 2 \mathrm{H}\right), 3.84(\mathrm{~s}, 6 \mathrm{H}), 3.84-3.75(\mathrm{~m}, 4 \mathrm{H}), 3.63-3.48(\mathrm{~m}, 10 \mathrm{H}), 3.35-3.31(\mathrm{~m}$, 2H), $2.41(\mathrm{t}, J=6.4 \mathrm{~Hz}, 4 \mathrm{H}), 2.33-2.27(\mathrm{~m}, 2 \mathrm{H}), 2.00-1.97(\mathrm{~m}, 6 \mathrm{H}), 1.26(\mathrm{~s}, 18 \mathrm{H}) .{ }^{13} \mathrm{C}-\mathrm{NMR}(100 \mathrm{MHz}$, $\left.\mathrm{CDCl}_{3}\right): \delta 173.8(2 \times \mathrm{CONH}), 169.1(2 \times \mathrm{COO}), 168.4(2 \times \mathrm{CON}), 166.8(2 \times \mathrm{CONH}), 160.2(2 \times$ Ar-C$\mathrm{OCH}_{3}$ ), 145.5 (2× Ar-C-SO 2 ), 137.0, 134.7, 132.0, 131.6 (Ar-C), 134.2, 130.4, 128.9, 128.5, 128.1,

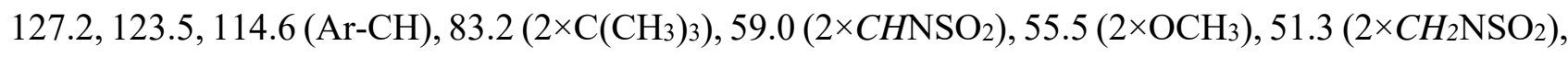

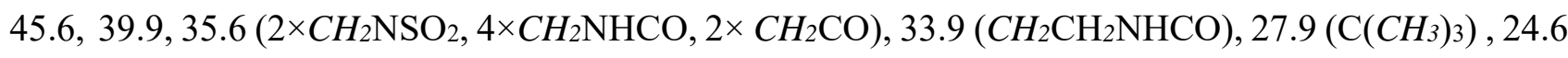
$\left(2 \times \mathrm{CH}_{2} \mathrm{CHNHCO}\right)$. Elemental Analysis for $\mathrm{C}_{78} \mathrm{H}_{86} \mathrm{~N}_{8} \mathrm{O}_{18} \mathrm{~S}_{2}$ calculated: \% C, 62.97; \% H, 5.83; \% N 7.53; found: \% $\mathrm{C}, 63.03 ; \% \mathrm{H}, 5.98 ; \% \mathrm{~N} 4.70$.

\subsubsection{Dimeric tert-butyl esters 27 and 28}

To a solution of acetate salt $\mathbf{2 5}^{20}$ (331 $\mathrm{mg}, 0.73 \mathrm{mmol}$ ) and dichloride $\mathbf{2 6}{ }^{16}$ (178 $\left.\mathrm{mg}, 0.48 \mathrm{mmol}\right)$ in dry DMF (5 mL), N,N-diisopropylethylamine (DIPEA) $(0.29 \mathrm{~mL}, 1.69 \mathrm{mmol})$ was added dropwise. The resulting mixture was stirred at rt overnight. The solvent was removed and the crude was dissolved in EtOAc, washed with $\mathrm{H}_{2} \mathrm{O}(1 \times 25 \mathrm{~mL})$ and brine $(1 \times 25 \mathrm{~mL})$. The organic phase was dried over $\mathrm{Na}_{2} \mathrm{SO}_{4}$, filtered and evaporated in vacuo. Compounds 27 (83 mg, 15\% yield) and 28 (91 mg, 23\% yield) were isolated after flash chromatography (EtOAc/n-hexane 1.5/1) as white solids. Compound 27: ${ }^{1} \mathrm{H}$ NMR (400 MHz, $\mathrm{CDCl}_{3}$ ): $\delta 8.36$ (brs, $\left.1 \mathrm{H}\right), 8.13$ (dd, $\left.J_{1}=7.6 \mathrm{~Hz}, J_{2}=1.6 \mathrm{~Hz}, 2 \mathrm{H}\right), 7.96-7.94(\mathrm{~m}, 4 \mathrm{H}, \mathrm{Ar}), 7.72-$ 7.69 (m, 4H, Ar), 7.60 (t, $J=8 \mathrm{~Hz}, 1 \mathrm{H}, \mathrm{Ar}), 7.56-7.53$ (m, 4H), 7.49-7.37 (m, 8H), 5.64 (d, J=9.2 Hz, $2 \mathrm{H}), 3.95-3.87(\mathrm{~m}, 4 \mathrm{H}), 3.65-3.57(\mathrm{~m}, 2 \mathrm{H}), 2.28-2.18(\mathrm{~m}, 2 \mathrm{H}), 1.80-1.71(\mathrm{~m}, 2 \mathrm{H}), 1.16(\mathrm{~s}, 18 \mathrm{H})$. 
Elemental Analysis for $\mathrm{C}_{48} \mathrm{H}_{54} \mathrm{~N}_{4} \mathrm{O}_{10} \mathrm{~S}_{2}$ calculated: $\% \mathrm{C}, 63.28 ; \% \mathrm{H}, 5.97 ; \% \mathrm{~N} 6.15$; found: \% $\mathrm{C}, 63.48$; $\% \mathrm{H}, 6.28 ; \% \mathrm{~N} 6.19$.

Compound 28: ${ }^{1} \mathrm{H}$ NMR (400 MHz, $\mathrm{CDCl}_{3}$ ): $\delta 8.25$ (brs, 1H), 8.12 (m, 4H, Ar), 7.92 (m, 4H, Ar), 7.71 (m, 4H, Ar), 7.58-7.40 (m, 11H), 5.36 (d, $J=9.1 \mathrm{~Hz}, 2 \mathrm{H}), 3.97$ (t, $J=7 \mathrm{~Hz}, 4 \mathrm{H}), 3.84-3.78$ (m, 2H), 3.5$3.44(\mathrm{~m}, 2 \mathrm{H}), 2.59$ (t, $J=7.8 \mathrm{~Hz}, 4 \mathrm{H}), 2.33-2.24(\mathrm{~m}, 2 \mathrm{H}), 2.24-2.10(\mathrm{~m}, 4 \mathrm{H}), 1.15(\mathrm{~s}, 18 \mathrm{H})$. Elemental Analysis for $\mathrm{C}_{56} \mathrm{H}_{68} \mathrm{~N}_{6} \mathrm{O}_{12} \mathrm{~S}_{2}$ calculated: $\% \mathrm{C}, 62.20 ; \% \mathrm{H}, 6.34 ; \% \mathrm{~N} 7.77$; found: $\% \mathrm{C}, 62.42 ; \% \mathrm{H}, 6.48$; $\%$ N 7.99.

\subsubsection{General procedure for the preparation of dimeric di-carboxylic acids 19, 23, 29 and} 30

Trifluoroacetic acid (TFA) (114 eq) was added dropwise to a solution of the appropriate tert-butyl ester (18 or 22 or 27 or 28$)(1 \mathrm{eq})$ in dry DCM $(1.5 \mathrm{~mL})$, cooled to $0{ }^{\circ} \mathrm{C}$. The reaction was stirred at rt overnight. The mixture was co-evaporated $(3 \times 10 \mathrm{~mL})$ with toluene/DCM and the crude was purified by trituration with $\mathrm{Et}_{2} \mathrm{O} / n$-hexane.

\subsubsection{Dimeric di-carboxylic acid 19}

The title compound was prepared from tert-butyl ester $18(56 \mathrm{mg}, 0.042 \mathrm{mmol})$ following the general procedure. The dicarboxylic acid 19 is a white solid (44 mg, 86\% yield). ${ }^{1} \mathrm{H}$ NMR (400 MHz, $\left.\mathrm{CDCl}_{3}\right): \delta$ 7.80-7.77 (m, 10H, Ar), 7.70-7.68 (m, 4H, Ar), 7.52-7.43 (m, 6H, Ar), 7.39-7.33 (m, 4H, Ar), 7.19-7.11 $(\mathrm{m}, 2 \mathrm{H}), 6.93-6.90(\mathrm{~m}, 4 \mathrm{H}, \mathrm{Ar}), 4.65-4.75(\mathrm{~m}, 2 \mathrm{H}), 3.83(\mathrm{~s}, 6 \mathrm{H}), 3.83-3.44(\mathrm{~m}, 12 \mathrm{H}), 2.51-2.42(\mathrm{~m}, 2 \mathrm{H})$, 2.10-1.95 (m, 2H). Elemental Analysis for $\mathrm{C}_{62} \mathrm{H}_{56} \mathrm{~N}_{6} \mathrm{O}_{16} \mathrm{~S}_{2}$ calculated: \% C, 61.78; \% H, 4.68; \% N 6.97; found: \% C, 61.96; \% H, 4.78; \% N 6.99 .

\subsubsection{Dimeric di-carboxylic acid 23}

The title compound was prepared from tert-butyl ester $22(55 \mathrm{mg}, 0.04 \mathrm{mmol})$ following the general procedure. The dicarboxylic acid 23 is a white solid (46 mg, 90\% yield). $\left.{ }^{1} \mathrm{H} \mathrm{NMR} \mathrm{(400} \mathrm{MHz,} \mathrm{CDCl}_{3}\right): \delta$ 8.12-8.10 (m, 1H), 7.95-7.36 (m, 23H, Ar), 6.99-6.95 (m, 4H, Ar), 4.55-4.52 (m, 2H), 3.84 (s, 6H), 3.66$3.73(\mathrm{~m}, 16 \mathrm{H}), 2.36-2.22(\mathrm{~m}, 6 \mathrm{H}), 2.00-1.79(\mathrm{~m}, 6 \mathrm{H})$. Elemental Analysis for $\mathrm{C}_{70} \mathrm{H}_{70} \mathrm{~N}_{8} \mathrm{O}_{18} \mathrm{~S}_{2}$ calculated: \% C, 61.12; \% H, 5.13; \% N 8.15; found: \% C, 61.48; \% H, 5.28; \% N 8.19.

\subsubsection{Dimeric di-carboxylic acid 29}

The title compound was prepared from tert-butyl ester $27(83 \mathrm{mg}, 0.09 \mathrm{mmol})$ following the general procedure. The dicarboxylic acid 29 is a white solid (63 mg, 86\% yield). ${ }^{1} \mathrm{H}$ NMR (400 MHz, CD $\left.3 \mathrm{OD}\right)$ : 反 8.24-8.23 (br t, 1H), 7.94-7.91 (m, 6H, Ar), 7.75 (m, 4H, Ar), 7.63 (m, 4H, Ar), 7.53-7.37 (m, 7H), 
$4.03\left(\mathrm{dd}, J_{1}=4.8 \mathrm{~Hz}, J_{2}=8.4 \mathrm{~Hz}, 2 \mathrm{H}\right), 3.61-3.55(\mathrm{~m}, 2 \mathrm{H}), 3.51-3.44(\mathrm{~m}, 2 \mathrm{H}), 2.19-2.11(\mathrm{~m}, 2 \mathrm{H}), 1.99-$ $1.90(\mathrm{~m}, 2 \mathrm{H})$. Elemental Analysis for $\mathrm{C}_{40} \mathrm{H}_{38} \mathrm{~N}_{4} \mathrm{O}_{10} \mathrm{~S}_{2}$ calculated: \% C, 60.14; \% H, 4.79; \% N 7.01; found: \% C, 60.34; \% H, 4.89; \% N 7.31 .

\subsubsection{Dimeric di-carboxylic acid 30}

The title compound was prepared from tert-butyl ester $\mathbf{2 8}(16 \mathrm{mg}, 0.01 \mathrm{mmol})$ following the general procedure. The crude product was purified using Isolute cartridge $\mathrm{C} 18\left(\mathrm{H}_{2} \mathrm{O}-\mathrm{MeOH} 2: 1\right)$ obtaining the dicarboxylic acid 30 is a white solid (46\% yield). M.p.: 119-121 ${ }^{\circ} \mathrm{C} ;{ }^{1} \mathrm{H}$ NMR (400 MHz, CD 3 OD): $\delta$ 8.04-8.03 (m, 2H), 7.94-7.88 (m, 6H), 7.74-7.71 (m, 6H), 7.64-7.62 (m, 4H), 7.48-7.44 (m, 6H), 7.417.39 (m, 2H), 3.94 (t, J=7.2 Hz, 4H), 3.83-3.80 (m, 2H), 3.48-3.45 (m, 2H), 2.60 (t, $J=8 \mathrm{~Hz}, 4 \mathrm{H}), 2.18$ $2.11(\mathrm{~m}, 4 \mathrm{H}), 2.01-1.96(\mathrm{~m}, 2 \mathrm{H}), 1.85-1.80(\mathrm{~m}, 2 \mathrm{H})$. Elemental Analysis for $\mathrm{C}_{48} \mathrm{H}_{52} \mathrm{~N}_{6} \mathrm{O}_{12} \mathrm{~S}_{2}$ calculated: \% C, 59.49; \% H, 5.41; \% N 8.67; found: \% C, 59.66; \% H, 5.62; \% N 8.75.

\section{General procedure for the preparation of dimeric di-hydroxamic acids 6, 7 and 8}

To a stirred solution of the appropriate dicarboxylic acid 19 or 23 or 29 (1 eq) in dry DMF (1 mL) 1hydroxybenzotriazole (HOBt) (2.4 eq), O-(tetrahydro-2h-pyran-2-yl)hydroxylamine $\left(\mathrm{THPONH}_{2}\right)(6.2$ eq), $N$-methylmorpholine (6 eq) and 1-[3-(Dimethylamino)propyl]-3-ethyl carbodiimide hydrochloride (EDC) $(2.8 \mathrm{eq})$ were added under nitrogen atmosphere. After stirring at rt overnight, the mixture was dissolved in EtOAc and washed with water, $\mathrm{NaHCO}_{3}$ saturated solution and brine. Then the organic phase was dried over $\mathrm{Na}_{2} \mathrm{SO}_{4}$ and evaporated in vacuum. The crude $O$-tetrahydropyranyl derivatives 20 , 24 and 31 were used in the next reaction without further purification. Tetrahydropyranyl precursor ( 1 eq) was then dissolved in a mixture of dioxane $(0.9 \mathrm{~mL})$ and methanol $(0.6 \mathrm{~mL})$ and a solution of $\mathrm{HCl} 4 \mathrm{~N}$ $(1.8 \mathrm{~mL} / \mathrm{mmol})$ was added dropwise at $0{ }^{\circ} \mathrm{C}$. After $2 \mathrm{~h}$ of stirring, the solvents were evaporated and the crude products were purified by flash chromatography using a Isolute Flash Si II cartridge to give the desired hydroxamic acids 6,7 and $\mathbf{8}$.

\subsubsection{Dimeric di-hydroxamic acid 6}

The title compound 6 was prepared starting from the carboxylic acid 19 (44 mg, 0.04 mmol) obtaining the tetrahydropyranyl derivative $\mathbf{2 0}(42 \mathrm{mg}, 0.03 \mathrm{mmol})$ following the general procedure. The crude product was purified by flash chromatography (in gradient from $\mathrm{CHCl}_{3}$ to $\mathrm{CHCl}_{3} / \mathrm{MeOH} 20: 1$ ) to give the hydroxamic acid 6 as white solid (20 mg, 48\% yield). M.p.: $158-160{ }^{\circ} \mathrm{C} ;{ }^{1} \mathrm{H}$ NMR $(400 \mathrm{MHz}$, DMSO$\left.d_{6}\right): \delta 10.84(\mathrm{~s}, 2 \mathrm{H}), 9.03(\mathrm{~s}, 2 \mathrm{H}) 8.68$ (brs, 2H), 8.28 (s, 1H), 7.87-7.78 (m, 18H, Ar), 7.70-7.68 (m, 4H, 
Ar), 7.39-7.35 (m, 1H, Ar), 7.10-7.04 (m, 4H, Ar), 4.34 (t, $J=7.6 \mathrm{~Hz}, 2 \mathrm{H}), 3.94-3.78$ (m, 2H), 3.81 (s, 3H), $3.46(\mathrm{~m}, 10 \mathrm{H}), 2.17-2.08(\mathrm{~m}, 2 \mathrm{H}), 1.94-1.92(\mathrm{~m}, 2 \mathrm{H}) .{ }^{13} \mathrm{C}$ NMR (100 MHz, DMSO-d6): $\delta 168.0$ $(2 \times \mathrm{CON}, 2 \times \mathrm{CONHOH}), 166.1(2 \times \mathrm{CONH}), 160.2\left(2 \times \mathrm{Ar}-\mathrm{C}-\mathrm{OCH}_{3}\right), 144.4\left(2 \times \mathrm{Ar}-\mathrm{C}-\mathrm{SO}_{2}\right), 137.0,, 132.1$, 131.0, 130.0,(Ar-C), 134.8, 128.8, 128.1, 127.2, 123.5, 115.0, (Ar- $\mathrm{CH}) 55.7\left(\mathrm{OCH}_{3}\right), 54.5\left(2 \times \mathrm{CHNSO}_{2}\right)$, 43.5, 35.09, ( $\left.2 \times \mathrm{CH}_{2} \mathrm{NCO}, 2 \times \mathrm{CH}_{2} \mathrm{NHCO}, 2 \times \mathrm{CH}_{2} \mathrm{NSO}_{2}\right), 29.8\left(\mathrm{CH}_{2} \mathrm{CHNSO}_{2}\right)$. Elemental Analysis for $\mathrm{C}_{62} \mathrm{H}_{58} \mathrm{~N}_{8} \mathrm{O}_{16} \mathrm{~S}_{2}$ calculated: \% C, 60.28; \% H, 4.73; \% N 9.07; found: \% C, 60.30; \% H, 4.78; \% N 9.10.

\subsubsection{Dimeric di-hydroxamic acid 7}

The title compound 7 was prepared starting from the di-carboxylic acid $\mathbf{2 3}$ (46 $\mathrm{mg}, 0.03 \mathrm{mmol}$ ) obtaining the tetrahydropyranyl derivative $24(42 \mathrm{mg}, 0.03 \mathrm{mmol})$ following the general procedure. The crude product was purified by flash chromatography (in gradient from $\mathrm{CHCl}_{3}$ to $\mathrm{CHCl}_{3} / \mathrm{MeOH} 50: 1$ ) to give the hydroxamic acid 7 as a white solid $\left(17 \mathrm{mg}, 48 \%\right.$ yield). M.p.: $128-131{ }^{\circ} \mathrm{C} ;{ }^{1} \mathrm{H}$ NMR (400 MHz, DMSO-d6): $\delta 10.82(\mathrm{~s}, 2 \mathrm{H}), 9.02(\mathrm{~s}, 2 \mathrm{H}) 8.57(\mathrm{t}, J=5.2 \mathrm{~Hz}, 2 \mathrm{H}), 8.28(\mathrm{~s}, 1 \mathrm{H}), 7.98-7.92(\mathrm{~m}, 4 \mathrm{H}, \mathrm{Ar})$, 7.86-7.77 (m, 15H, Ar), 7.69 (m, 4H, Ar), 7.53-7.51 (m, 1H, Ar), 7.05 (m, 4H), 4.29 (t, J=7.6 Hz, 2H), $3.81(\mathrm{~s}, 6 \mathrm{H}), 3.68-3.20(\mathrm{~m}, 16 \mathrm{H}), 2.11-2.08(\mathrm{~m}, 6 \mathrm{H}), 1.86-1.83(\mathrm{~m}, 2 \mathrm{H}), 1.70(\mathrm{t}, J=7.2 \mathrm{~Hz}, 4 \mathrm{H}) .{ }^{13} \mathrm{C}$ NMR (100 MHz, DMSO-d 6$): \delta 171.9\left(2 \times \mathrm{CH}_{2} \mathrm{CONH}\right), 169.6(2 \times \mathrm{CONHOH}), 167.6(2 \times \mathrm{CON}), 165.8$ $(2 \times \mathrm{CONH}) 159.8\left(\mathrm{Ar}-\mathrm{C}-\mathrm{OCH}_{3}\right), 143.9\left(\mathrm{Ar}-\mathrm{C}-\mathrm{SO}_{2}\right), 136.6,130.5,129.5,134.8,(\mathrm{Ar}-\mathrm{C}), 131.7,128.3$, 127.6, 126.7, 123.0, 114.5, (Ar-CH), $55.2\left(2 \times \mathrm{OCH}_{3}\right), 54.5\left(2 \times \mathrm{CHNSO}_{2}\right), 43.4,\left(2 \times \mathrm{CH}_{2} \mathrm{NSO}_{2}\right), 34.6-32.8$ $\left(4 \times \mathrm{CH}_{2} \mathrm{NHCO}, 2 \times \mathrm{CH}_{2} \mathrm{NCO}, 4 \times \mathrm{CH}_{2} \mathrm{CO}\right), 29.6\left(2 \times \mathrm{CH}_{2} \mathrm{CH}_{2} \mathrm{NHCO}\right), 25.1\left(2 \times \mathrm{CH}_{2} \mathrm{CHNHCO}\right)$. Elemental Analysis for $\mathrm{C}_{70} \mathrm{H}_{72} \mathrm{~N}_{10} \mathrm{O}_{18} \mathrm{~S}_{2}$ calculated: $\% \mathrm{C}, 59.82 ; \% \mathrm{H}, 5.16 ; \% \mathrm{~N}$ 9.97; found: \% $\mathrm{C}, 59.86$; \% $\mathrm{H}$, $5.20 ; \% \mathrm{~N} 9.94$.

\subsubsection{Dimeric di-hydroxamic acid 8}

The title compound 8 was prepared starting from the carboxylic acid 29 (63 $\mathrm{mg}, 0.08 \mathrm{mmol}$ ) obtaining the tetrahydropyranyl derivative $31(42 \mathrm{mg} 0.03 \mathrm{mmol})$ following the general procedure. The crude product was purified by flash chromatography using Isolute cartridge $\mathrm{C} 18\left(\mathrm{H}_{2} \mathrm{O}-\mathrm{MeOH} 2: 1\right)$ to give the hydroxamic acid 8 as white solid (6 mg, $10 \%$ yield). M.p.: 152-153 ${ }^{\circ} \mathrm{C} ;{ }^{1} \mathrm{H}$ NMR (400 MHz, DMSO$\left.d_{6}\right): \delta 10.65$ (s, 2H), 8.94 (s, 2H), 8.44 (br t, 2H), 8.23 (br s, 3H, Ar), 7.89-7.77 (m, 10H, Ar), 7.68-7.66 (m, 4H, Ar), 7.50-7.41 (m, 7H, Ar), 3.73-3.72 (m, 2H), 3.17-3.16 (m, 4H), 1.83-1.80 (m, 2H), 1.68-1.64 $(\mathrm{m}, 2 \mathrm{H}) .{ }^{13} \mathrm{C}$ NMR $\left(100 \mathrm{MHz}, \mathrm{DMSO}-d_{6}\right): \delta 166.8,165.7(2 \times \mathrm{CONH} 2 \times \mathrm{CONHOH}), 143.6\left(\mathrm{Ar}-\mathrm{C}-\mathrm{SO}_{2}\right)$, 140.0, 138.4, 134.4, 129.6, 129.0, 127.1,( Ar-CH), 126.9, 126.9, 128.3, 128.1, 126.1,( Ar-C) 52.1 $\left(2 \times \mathrm{CHNSO}_{2}\right), 48.5,45.6,36.1,32.6\left(2 \times \mathrm{CH}_{2} \mathrm{CHNHSO}_{2}, 2 \times \mathrm{CH}_{2} \mathrm{NHCO}\right)$. Elemental Analysis for 
$\mathrm{C}_{40} \mathrm{H}_{40} \mathrm{~N}_{6} \mathrm{O}_{10} \mathrm{~S}_{2}$ calculated: $\% \mathrm{C}, 57.96 ; \% \mathrm{H}, 4.86 ; \% \mathrm{~N}, 10.14$; found: $\% \mathrm{C}, 57.99 ; \% \mathrm{H}, 4.90 ; \% \mathrm{~N}$, 10.10 .

\subsubsection{Dimeric hydroxamic acid 9}

1-[3-(Dimethylamino)propyl]-3-ethyl carbodiimide hydrochloride (EDC) was added portionwise (49.85 $\mathrm{mg}, 0.26 \mathrm{mmol})$ to a stirred and cooled solution $\left(0^{\circ} \mathrm{C}\right)$ of the carboxylic acid $30(84 \mathrm{mg}, 0.09 \mathrm{mmol})$ and O-(tert-butyldimethylsilyl)-hydroxylamine $(38 \mathrm{mg}, 0.26 \mathrm{mmol})$ in dry DCM $(3 \mathrm{~mL})$. After stirring at $\mathrm{rt}$ overnight, the mixture was washed with water, and the organic phase was dried and evaporated in vacuo. The crude was purified by flash chromatography trough Isolute cartridge SI II $\left(\mathrm{CHCl}_{3}\right)$ to afford the silyl derivative 32 as a white solid (16 mg, 15\% yield). ${ }^{1} \mathrm{H}$ NMR (400 MHz, $\left.\mathrm{CDCl}_{3}\right): \delta 10.34(\mathrm{~s}, 2 \mathrm{H}), 8.14-$ 7.36 (m, 22H), 6.13 (d, $J=8 \mathrm{~Hz}, 2 \mathrm{H}), 4.00-3.84$ (m, 6H), 3.48-3.22 (m, 2H), 2.61-2.53 (m, 4H), 2.16$1.99(\mathrm{~m}, 8 \mathrm{H}), 0.81(\mathrm{~s}, 18 \mathrm{H}), 0.07(\mathrm{~s}, 12 \mathrm{H})$.

Silyl precursor $32(16 \mathrm{mg}, 0.01 \mathrm{mmol})$ was then dissolved in dry $\mathrm{CH}_{2} \mathrm{Cl}_{2}(1 \mathrm{~mL})$, and trifluoroacetic acid (TFA) $(0.1 \mathrm{~mL}, 1.49 \mathrm{mmol}, 114 \mathrm{eq})$ was added dropwise at $0{ }^{\circ} \mathrm{C}$. After $5 \mathrm{~h}$ of stirring at $\mathrm{rt}$, the solvent was evaporated. The crude product was purified by flash chromatography through Isolute cartridge $\mathrm{C} 18$ $\left(2: 1 \mathrm{H}_{2} \mathrm{O}-\mathrm{MeOH}\right)$ affording hydroxamic acid 9 (6 mg, 46\% yield) as a white solid. M.p.: $119-120{ }^{\circ} \mathrm{C} ;{ }^{1} \mathrm{H}$ NMR (400 MHz, CD 3 OD): $\delta 8.03$ (br t, 2H), 7.94-7.88 (m, 6H), 7.74-7.71 (m, 6H), 7.64-7.62 (m, 4H), 7.48-7.44 (m, 6H), 7.41-7.39 (m, 2H), $3.94(\mathrm{t}, J=7.2 \mathrm{~Hz}, 4 \mathrm{H}), 3.81\left(\mathrm{dd}, J_{1}=6 \mathrm{~Hz}, J_{2}=8 \mathrm{~Hz} 2 \mathrm{H}\right), 3.48$ $3.45(\mathrm{~m}, 2 \mathrm{H}), 2.60(\mathrm{t}, J=8 \mathrm{~Hz}, 4 \mathrm{H}), 2.18-2.11(\mathrm{~m}, 4 \mathrm{H}), 2.01-1.96(\mathrm{~m}, 2 \mathrm{H}), 1.85-1.80(\mathrm{~m}, 2 \mathrm{H}) .{ }^{13} \mathrm{C}$ NMR

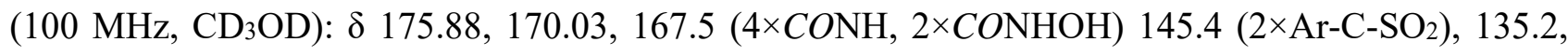
133.5, 131.3, 129.8 (Ar-C) 139.2, 138.9, 128.6, 128.0, 127.7, 127.3, 127.2, 126.9 (Ar-CH), $52.3\left(2 \times \mathrm{CHNSO}_{2}\right), 47.6,46.2\left(4 \times \mathrm{CH}_{2} \mathrm{NHCO}\right), 36.1\left(2 \times \mathrm{NHCO}_{2} \mathrm{CH}_{2}\right), 32.5\left(2 \times \mathrm{CH}_{2} \mathrm{CH}_{2} \mathrm{NHCO}\right)$, $4 \times \mathrm{CH}_{2} \mathrm{NHCO}$,), $17.12\left(2 \times \mathrm{CH}_{2} \mathrm{CHNHSO}_{2}\right)$. Elemental Analysis for $\mathrm{C}_{48} \mathrm{H}_{54} \mathrm{~N}_{8} \mathrm{O}_{12} \mathrm{~S}_{2}$ calculated: \% C, 57.70; \% H, 5.45; \% N 11.22; found: \% C, 57.78; \% H, 5.50; \% N 11.18 .

\subsection{MMP Inhibition Assays.}

Recombinant human proMMP-2, proMMP-9 and proMMP-1 were purchased from Calbiochem (Merck Millipore). MMP-14 catalytic domain was a kind gift of Prof. Gillian Murphy (Department of Oncology, University of Cambridge, UK). Proenzymes were activated immediately prior to use with paminophenylmercuric acetate (APMA $2 \mathrm{mM}$ for $1 \mathrm{~h}$ at $37{ }^{\circ} \mathrm{C}$ for MMP-2, $1 \mathrm{mM}$ for $1 \mathrm{~h}$ at $37{ }^{\circ} \mathrm{C}$ for MMP-9, $2 \mathrm{mM}$ for $2 \mathrm{~h}$ at $37^{\circ} \mathrm{C}$ for MMP-1). For assay measurements, the inhibitor stock solutions (DMSO, $10 \mathrm{mM}$ ) were further diluted in the fluorimetric assay buffer (FAB: Tris $50 \mathrm{mM}, \mathrm{pH}=7.5, \mathrm{NaCl}$ $150 \mathrm{mM}, \mathrm{CaCl}_{2} 10 \mathrm{mM}$, Brij 35 0.05\%, and DMSO 1\%). Activated enzyme (final concentration $0.5 \mathrm{nM}$ 
for MMP-2, $1.3 \mathrm{nM}$ for MMP-9, $1.0 \mathrm{nM}$ for MMP-14 cd, $2.0 \mathrm{nM}$ for MMP-1) and inhibitor solutions were incubated in the assay buffer for $3 \mathrm{~h}$ at $25{ }^{\circ} \mathrm{C}$. After the addition of $200 \mu \mathrm{M}$ solution of the fluorogenic substrate Mca-Lys-Pro-Leu-Gly-Leu-Dap(Dnp)-Ala-Arg-NH2 (Calbiochem) in DMSO (final concentration $2 \mu \mathrm{M}$ ), the hydrolysis was monitored every $10 \mathrm{~s}$ for $15 \mathrm{~min}$ recording the increase in fluorescence $\left(\lambda_{\mathrm{ex}}=325 \mathrm{~nm}, \lambda_{\mathrm{em}}=400 \mathrm{~nm}\right)$ using a Molecular Devices SpectraMax Gemini XPS plate reader. The assays were performed in a total volume of $200 \mu \mathrm{L}$ per well in 96-well microtiter plates (Corning, black, NBS). Control wells lack inhibitor. The MMP inhibition activity was expressed in relative fluorescent units (RFU). Percent of inhibition was calculated from control reactions without the inhibitor. IC 50 was determined using the formula: $\mathrm{v}_{\mathrm{i}} / \mathrm{v}_{0}=1 /(1+[\mathrm{I}] / \mathrm{IC} 50)$, where $\mathrm{V}_{\mathrm{i}}$ is the initial velocity of substrate cleavage in the presence of the inhibitor at concentration [I] and $v_{0}$ is the initial velocity in the absence of the inhibitor. Results were analyzed using SoftMax Pro software and GraFit software.

\subsection{Materials and methods of the biological experiments}

\subsubsection{Cell Culture}

HT1080 cells were cultured in DMEM (Lonza) supplemented with $10 \%$ of FBS (GIBCO) and penicillin/streptomycin (PAA) at $37^{\circ} \mathrm{C}, 5 \% \mathrm{CO}_{2}$.

\subsubsection{Antibodies and Reagents}

The following primary antibody were used: mouse anti-MT1-MMP monoclonal antibody (clone 2221D8, WB: 1:1000), mouse anti-actin monoclonal antibody (clone C4, sc47778, Santa Cruz, WB: 1:1000). The following secondary antibody was used: IRDye ${ }^{\circledR} 800 \mathrm{CW}$ conjugated goat anti-mouse $\operatorname{IgG}(\mathrm{H}+\mathrm{L}$, P/N 926-32210, Li-Cor biosciences, WB: 1:10000).

GM6001 was from Elastin Products Company, PureCol bovine collagen type I was from Inamed Biomaterials, Cellmatrix type I-A collagen was from Nitta, Cytodex 3 microcarrier beads (Cytodex 3: 133-215 $\mu \mathrm{m})$ were from Sigma. MTS was from abcam.

\subsubsection{MTS colorimetric assay}

HT1080 cells were seeded in the amount of $8 \times 10^{3}$ cells/well in a 96-well plate and they were cultured overnight in the presence of compounds 4 and 6. MTS (3-(4,5 dimethylthiazol-2-yl)-5-(3carboxymethoxyphenyl)2-(4-sulfophenyl)-2H-tetrazolium) in PMS (phenazine methosulphate) was added to each well and cells were incubated for $4 \mathrm{~h}$, the absorbance at $490 \mathrm{~nm}$ was measured every $\mathrm{h}$ using an ELISA plate reader (FLUOstar Omega, BMG Labtech).

\subsubsection{Western Blotting}

Cell lysates were prepared using SDS-PAGE loading buffer, containing 2-mercaptoethanol and subjected to SDS-PAGE, they were then transferred to PVDF membranes using the Trans-Blot Turbo Transfer 
system (Bio-Rad). After blocking with 10\% dry milk in TBS (20 mM Tris-HCl, pH 7.5, $150 \mathrm{mM} \mathrm{NaCl})$, membranes were probed with mouse anti-MT1-MMP monoclonal antibody or mouse anti-actin monoclonal antibody, protein bands were visualized using IRDye-near-infrared secondary antibodies.

\subsubsection{Gelatin Zymography}

HT1080 cells were seeded in the amount of 5 X $10^{4}$ cells/well in a 12 well plate, after $24 \mathrm{~h}$, media was replaced with serum-free DMEM containing collagen (PureCol, final concentration $50 \mu \mathrm{g} / \mathrm{mL}$ ) and GM6001 $(10 \mu \mathrm{M})$ or compounds 4 or $6(1 \mu \mathrm{M}, 10 \mu \mathrm{M})$. DMSO-containing media was used as negative control. After $24 \mathrm{~h}$, samples were recovered, mixed with SDS-PAGE loading buffer without 2mercaptoethanol and subjected to electrophoresis using an SDS-polyacrylamide gel containing gelatin $(0.8 \mathrm{mg} / \mathrm{mL})$. Enzyme activity was visualized as negative staining with Coomassie Blue.

\subsubsection{Collagen Film Degradation Assay}

Collagen film degradation assay was performed as previously described.$^{30}$ In brief, a thin layer of ice cold neutralized collagen (1:1 mixture of PureCol and Cellmatrix type I-A collagen, final concentration $2 \mathrm{mg} / \mathrm{mL}$ ) was used to coat 12 -well culture plates, HT1080 cells were seeded on the film in the amount of 1 X $10^{5}$ cells/ well and cultured in the presence of GM6001 $(10 \mu \mathrm{M})$ or compounds 4 or $6(1 \mu \mathrm{M}, 10$ $\mu \mathrm{M})$. DMSO-containing media was used as negative control. After $48 \mathrm{~h}$, cells were trypsinized and remaining collagen was fixed with $4 \%$ formaldehyde. Collagen was visualized by staining with Coomassie Blue.

Image acquisition and analysis

Representative images were acquired using the 10x dry lens $(\mathrm{NA}=0.3)$ of a Nikon TE2000-E microscope equipped with an ORCA-ER CCD camera (Hammamatsu Photonics) operated by Volocity Acquisition module software (Improvision, PerkinElmer). To quantify collagen film degradation, integrated density of the collagen layer was measured using ImageJ software (National Institutes of Health, Bethesda, MD, USA). Mean integrated densities were calculated and plotted with error bars representing the standard deviation (SD), using Prism 6 (GraphPad Software, La Jolla, CA, USA). Data were compared using oneway ANOVA statistical analysis.

\subsubsection{Microcarrier Beads Invasion Assay}

Microcarrier beads invasion assay was carried out as previously described. ${ }^{31}$ HT 1080 cells were attached to gelatin-coated Cytodex 3 microcarrier beads by preparing a cells/beads suspension which was incubated on a shaker for $6 \mathrm{~h}$. Beads coated with cells were suspended in neutralized collagen (Cellmatrix type I-A, final concentration $2 \mathrm{~mL} / \mathrm{mL})$ and incubated overnight in the presence of either GM6001 (10 
$\mu \mathrm{M})$ or inhibitor $4(1 \mu \mathrm{M}, 10 \mu \mathrm{M})$ or inhibitor $6(1 \mu \mathrm{M}, 10 \mu \mathrm{M})$. DMSO-containing media was used as negative control.

Image acquisition and analysis

Images of the beads/cells were acquired using the 10x dry lens (NA $=0.3)$ of a Nikon TE2000-E microscope equipped with an ORCA-ER CCD camera (Hammamatsu Photonics) operated by Volocity Acquisition module software (Improvision, PerkinElmer). To quantify collagen invasion, the distance between a cell nucleus and the surface of the bead was measured using the line tool of ImageJ software (National Institutes of Health, Bethesda, MD, USA). Only well-focused cells were included in the calculation and mean migrated distances were calculated taking into consideration 50 cells per treatment. Mean migrated distances were calculated and plotted with SD, using Prism 6 (GraphPad Software, La Jolla, CA, USA). Data were compared using one-way ANOVA statistical analysis.

\subsection{Molecular modeling studies}

All simulations were performed using AMBER, version $14 .{ }^{32}$ A high resolution structure of a MMP-9inhibitor-MMP-9 trimer has been already reported (PDB id: 4H82). On this basis, two MT1-MMP catalytic domains have been superimposed to the MMP-9-inhibitor-MMP-9 trimer in order to create a MT1-MMP dimer. The system was then solvated with a $20 \AA$ water cap. Sodium ions were added as counterions to neutralize the system. Prior to MD simulations, two steps of energy minimization were carried out. In the first stage, we kept the dimer fixed with a position restraint of $100 \mathrm{kcal} \mathrm{mol}^{-1} \AA^{-2}$ and we just energy minimized the positions of the water molecules. In the second stage, we energy minimized the whole system without applying constraints. The two energy minimization stages consisted of 10000 steps. The first 1000 steps were Steepest Descent, and the last 9000 were Conjugate Gradient (CG). The MD trajectory was run using the energy minimized structure as the input, and particle mesh Ewald electrostatics and periodic boundary conditions were used in the simulation. The time step of the simulations was $2.0 \mathrm{fs}$ with a cutoff of $10 \AA$ for the non-bonded interaction. SHAKE was employed to keep all bonds involving hydrogen atoms rigid. A constant-volume was carried out for 500 ps, during which time the temperature was raised from 0 to $300 \mathrm{~K}$ (using the Langevin dynamics method). Then, $50 \mathrm{~ns}$ of constant-pressure MD were carried out at $300 \mathrm{~K}$. The final structure was obtained as the average of the last $25 \mathrm{~ns}$ of MD energy minimized with the CG method until a convergence of $0.05 \mathrm{kcal} \mathrm{mol}^{-1} \AA^{-}$ ${ }^{2}$ was reached. Automated docking of compound 6 was carried out by means of the Gold program (version 5.1). ${ }^{33}$ The region of interest used by Gold was defined in order to contain the residues within $20 \AA$ from the catalytic zinc ions. The "allow early termination" option was deactivated while the remaining Gold default parameters were used, and the ligand was submitted to 200 genetic algorithm runs by applying 
the ChemScore fitness function. The best docked conformation was taken into account. The General Amber Force Field (GAFF) parameters were assigned to the ligand. The partial charges were calculated using the AM1-BCC method, as implemented in the Antechamber suite of AMBER 14. The corresponding MT1-MMP-6-MT1-MMP trimer thus obtained was subjected to $100 \mathrm{~ns}$ with the same procedure described above. The final structure was obtained as the average of the last $50 \mathrm{~ns}$ of MD energy minimized with the CG method until a convergence of $0.05 \mathrm{kcal} \mathrm{mol}^{-1} \AA^{-2}$ was reached.

\section{Acknowledgements}

This work has been supported by funding from University of Pisa (PRA_2017_51 and PRA_2018_20) and from Kennedy Trust Prize Studentships for V. Gifford.

\section{Supplementary Data}

Supplementary data associated with this article can be found, in the online version, at

\section{References}

${ }^{1}$ Nagase H, Visse R, Murphy G. Structure and function of matrix Metalloproteinases and TIMPs. Cardiovascular Research, 2006;69:562-573.

${ }^{2}$ Itoh Y. Membrane-type matrix metalloproteinases: Their functions and regulations. Matrix Biol. $2015 ; 44-46: 207-223$.

${ }^{3}$ Barbolina MV, Stack SS. Membrane type 1-matrix metalloproteinase: Substrate diversity in pericellular proteolysis. Semin Cell Dev Biol. 2008;19:24-33.

${ }^{4}$ Will H, Atkinson SJ, Butler SG, Smith B, Murphy G. The soluble catalytic domain of membrane type 1 Matrix Metalloproteinase cleaves the propeptide of progelatinase A and initiates autoproteolytic activation regulation by TIMP-2 and TIMP-3. J Biol Chem. 1996;271:17119-17123.

${ }^{5}$ Knäuper V, Will H, López-Otin C, Smith B, Atkinson SJ, Stanton H, Hembry RM, Murphy G. Cellular mechanisms for human procollagenase-3 (MMP-13) activation. Evidence that MT1-MMP (MMP-14) and gelatinase a (MMP-2) are able to generate active enzyme. J Biol Chem. 1996;271:17124-17131. 
${ }^{6}$ Sato H, Takino T. Coordinate action of membrane-type matrix metalloproteinase-1 (MT1-MMP) and MMP-2 enhances pericellular proteolysis and invasion. Cancer Sci. 2010;101:843-847.

${ }^{7}$ Zeng Z, Cohen AM, Guillem JG. Loss of basement membrane type IV collagen is associated with increased expression of metalloproteinases 2 and 9 (MMP-2 and MMP-9) during human colorectal tumorigenesis. Carcinogenesis 1999;20:749-755.

${ }^{8}$ Itoh Y, Takamura A, Ito N, Maru Y, Sato H, Suenaga N, Aoki T, Seiki M. Homophilic complex formation of MT1-MMP facilitates proMMP-2 activation on the cell surface and promotes tumor cell invasion. EMBO J. 2001;20:4782-4793.

${ }^{9}$ Itoh Y, Ito N, Nagase H, Seiki M. The second dimer interface of MT1-MMP, the transmembrane domain, is essential for ProMMP-2 activation on the cell surface. J Biol Chem. 2008;283:13053-13062.

${ }^{10}$ Itoh Y, Ito N, Nagase H, Evans RD, Bird SA, Seiki M. Cell surface collagenolysis requires homodimerization of the membrane-bound collagenase MT1-MMP. Mol Biol Cell. 2006;17:5390-5399. ${ }^{11}$ Mendes DE, Wong-On-Wing A, Berkman CE. Phosphoramidate-based peptidomimetic inhibitors of membrane type-1 matrix metalloproteinase. J Enzyme Inhib Med Chem. 2016;31:167-171.

${ }^{12}$ Suojanen J, Salo T, Koivunen E, Sorsa T, Pirilä E. A novel and selective membrane type-1 matrix metalloproteinase (MT1-MMP)inhibitor reduces cancer cell motility and tumor growth. Cancer Biol Ther. 2009;8:2362-2370.

${ }^{13}$ Remacle AG, Golubkov VS, Shiryaev SA, Dahl R, Stebbins JL, Chernov AV, Cheltsov AV, Pellecchia M, Strongin AY. Novel MT1-MMP small-molecule inhibitors based on insights into hemopexin domain function in tumor growth. Cancer Res. 2012;72:2339-2349.

14 a) Ugarte-Berzal E, Bailón E, Amigo-Jiménez I, Vituri CL, del Cerro MH, Terol MJ, Albar JP, Rivas G, García-Marco JA, García-Pardo A. A 17-residue sequence from the matrix metalloproteinase-9 (MMP-9) hemopexin domain binds $\alpha 4 \beta 1$ integrin and inhibits MMP-9-induced functions in chronic lymphocytic leukemia B cells. J Biol Chem. 2012;287:27601-27613. b) Dufour A, Sampson NS, Li J, 
Kuscu C, Rizzo RC, Deleon JL, Zhi J, Jaber N, Liu E, Zucker S, Cao J. Small-molecule anticancer compounds selectively target the hemopexin domain of matrix metalloproteinase-9. Cancer Res. 2011;71:4977-4988.

${ }^{15}$ Nuti E, Rosalia L, Cuffaro D, Camodeca C, Giacomelli C, Da Pozzo E, Tuccinardi T, Costa B, Antoni C, Vera L, Ciccone L, Orlandini E, Nencetti S, Dive V, Martini C, Stura EA, Rossello A. Bifunctional Inhibitors as a New Tool To Reduce Cancer Cell Invasion by Impairing MMP-9 Homodimerization. ACS Med Chem Lett. 2017;8:293-298.

${ }^{16}$ Rossello A, Nuti E, Catalani MP, Carelli P, Orlandini E, Rapposelli S, Tuccinardi T, Atkinson SJ, Murphy G, Balsamo A. A new development of matrix metalloproteinase inhibitors: twin hydroxamic acids as potent inhibitors of MMPs. Bioorg Med Chem Lett. 2005;15:2311-2314.

${ }^{17}$ Wang J, Radomski MW, Medina C, Gilmer JF. MMP inhibition by barbiturate homodimers. Bioorg Med Chem Lett. 2013;23:444-447.

${ }^{18}$ Contreras JM, Sippl W. Homo and heterodimer ligands: the twin drug approach. In: Camille-Georges Wermuth, eds. The Practice of Medicinal Chemistry. Academic Press, 2008:380-414.

${ }^{19}$ Nuti E, Cantelmo AR, Gallo C, Bruno A, Bassani B, Camodeca C, Tuccinardi T, Vera L, Orlandini E, Nencetti S, Stura EA, Martinelli A, Dive V, Albini A, Rossello A. N-O-Isopropyl Sulfonamido-Based Hydroxamates as Matrix Metalloproteinase Inhibitors: Hit Selection and in Vivo Antiangiogenic Activity. J Med Chem. 2015;58:7224-7240.

${ }^{20}$ Nuti E, Casalini F, Avramova SI, Santamaria S, Fabbi M, Ferrini S, Marinelli L, La Pietra V, Limongelli V, Novellino E, Cercignani G, Orlandini E, Nencetti S, Rossello A. Potent arylsulfonamide inhibitors of tumor necrosis factor-alpha converting enzyme able to reduce activated leukocyte cell adhesion molecule shedding in cancer cell models. J Med Chem. 2010;53:2622-2635.

${ }^{21}$ Rossello A, Nuti E, Orlandini E, Balsamo A, Tuccinardi T. Compounds having aryl-sulphonamidic structure useful as metalloproteases inhibitors. Patent WO2008113756, 2008. 
${ }^{22}$ Santamaria S, Nagase H. Measurement of Protease Activities Using Fluorogenic Substrates. Methods Mol Biol. 2018;1731:107-122.

${ }^{23}$ Becker DP, Barta TE, Bedell LJ, Boehm TL, Bond BR, Carroll J, Carron CP, Decrescenzo GA, Easton AM, Freskos JN, Funckes-Shippy CL, Heron M, Hockerman S, Howard CP, Kiefer JR, Li MH, Mathis KJ, McDonald JJ, Mehta PP, Munie GE, Sunyer T, Swearingen CA, Villamil CI, Welsch D, Williams JM, Yu Y, Yao J. Orally active MMP-1 sparing $\alpha$-tetrahydropyranyl and $\alpha$-piperidinyl sulfone matrix metalloproteinase (MMP) inhibitors with efficacy in cancer, arthritis, and cardiovascular disease. $J$ Med Chem. 2010;53:6653-6680.

${ }^{24}$ Sato H, Takino T, Okada Y, Cao J, Shinagawa A, Yamamoto E, Seiki M. A matrix metalloproteinase expressed on the surface of invasive tumour cells. Nature. 1994;7:61-65.

${ }^{25}$ Woskowicz AM, Weaver SA, Shitomi Y, Ito N, Itoh Y. MT-LOOP-dependent localization of membrane type I matrix metalloproteinase (MT1-MMP) to the cell adhesion complexes promotes cancer cell invasion. J Biol Chem. 2013;288:35126-35137.

${ }^{26}$ Haas TL, Davis SJ, Madri JA. Three-dimensional type I collagen lattices induce coordinate expression of matrix metalloproteinases MT1-MMP and MMP-2 in microvascular endothelial cells. $J$ Biol Chem. 1998;273:3604-3610.

${ }^{27}$ a) Hotary K, Allen E, Punturieri A, Yana I, Weiss SJ. Regulation of cell invasion and morphogenesis in a three-dimensional type I collagen matrix by membrane-type matrix metalloproteinases 1,2 , and 3. $J$ Cell Biol. 2000;149:1309-1323. b) Hotary KB, Allen ED, Brooks PC, Datta NS, Long MW, Weiss SJ. Membrane type I matrix metalloproteinase usurps tumor growth control imposed by the threedimensional extracellular matrix. Cell. 2003;114:33-45.

${ }^{28}$ Antoni C, Vera L, Devel L, Catalani MP, Czarny B, Cassar-Lajeunesse E, Nuti E, Rossello A, Dive V, Stura EA. Crystallization of bi-functional ligand protein complexes. J Struct Biol. 2013; 182:246-254. 
${ }^{29}$ MacPherson LJ, Bayburt EK, Capparelli MP, Carroll BJ, Goldstein R, Justice MR, Zhu LJ, Hu SI, Melton RA, Fryer L, Goldberg RL, Doughty JR, Spirito S, Blancuzzi V, Wilson D, O’Byrne EM, Ganu V, Parker DT. Discovery of CGS 27023A, a non-peptidic, potent, and orally active stromelysin inhibitor that blocks cartilage degradation in rabbits. J Med Chem. 1997;40:2525-2532.

${ }^{30}$ Evans RD, Itoh Y. Analyses of MT1-MMP activity in cells. Methods Mol Med. 2007;135:239-249.

${ }^{31}$ Palmisano R, Itoh Y. Analysis of MMP-dependent cell migration and invasion. Methods Mol Biol 2010;622:379-392.

${ }^{32}$ Case DA, Berryman JT, Betz RM, Cerutti DS, Cheatham III TE, Darden TA, Duke RE, Giese TJ, Gohlke H, Goetz AW, Homeyer N, Izadi S, Janowski P, Kaus J, Kovalenko A, Lee TS, LeGrand S, Li P, Luchko T, Luo R, Madej B, Merz KM, Monard G, Needham P, Nguyen H, Nguyen HT, Omelyan I, Onufriev A, Roe DR, Roitberg A, Salomon-Ferrer R, Simmerling CL, Smith W, Swails J, Walker RC, Wang J, Wolf RM, Wu X, York DM, Kollman PA. AMBER, Version 14; University of California: San Francisco, CA, 2015.

${ }^{33}$ Verdonk ML, Cole JC, Hartshorn MJ, Murray CW, Taylor RD. Improved protein-ligand docking using GOLD. Proteins 2003;52:609-623. 